\title{
The interaction effect of foreign capital inflows and financial development on economic welfare in sub-Saharan Africa
}

\author{
Kwame Acheampong
}

\author{
Correspondence: kacheampong35@ \\ yahoo.com; kwame.74. \\ acheampong@gmail.com \\ Department of Economics and \\ Statistics, Garden City Business \\ School, Garden City University \\ College, Kenyase, P. O. Box KS \\ 15490, Kumasi, Ghana
}

\begin{abstract}
This study examines the interaction effects of foreign capital inflows and financial development on economic welfare in sub-Saharan Africa (SSA). Estimates based on the system-GMM estimator using panel data on 23 SSA countries for 2000 to 2013 establish several results. First, the interaction between foreign capital inflows and financial development positively affects economic welfare in SSA. However, this effect was negative after one year. Second, the partial indirect effects of foreign capital inflows on economic welfare, conditional on the level of financial development, are positive, though they become negative after one year. Third, the total effect of foreign capital inflows on economic welfare is positive. The effect becomes negative after a year, though the predominant source of financial development is domestic credit. The consistency of these results indicates the importance of financial development in transmitting foreign capital to economic welfare enhancement. Developing the SSA's financial sector to meet specific welfare-enhancing demands may potentially convert a large share of capital inflows into improved economic welfare and eliminate the negative effects.
\end{abstract}

Keywords: Economic welfare enhancement, Foreign direct investment, Official creditors, Domestic credit, Money supply

JEL: D63, F30, G00

\section{Introduction}

Greenwood and Jovanovic (1990) suggest that financial development directly affects economic welfare over time. In contrast, Kuznets (1955) claims that investment in human capital is a conduit that enhances economic agents' welfare. Both theoretical suppositions indicate the importance of improving economic welfare through financial development (FD) and increased investment in human capital. With foreign capital inflows (FCF) increasing recently in sub-Saharan Africa (SSA) (Table 1), it leaves one to wonder if these flows improve FD to augment an investment in human capital, or whether FD induces foreign capital to enhance the investment in human capital. This study empirically examines the potential interaction effect between FD and FCF on economic welfare enhancement in SSA.

Foreign capital augments domestic resources in many ways, such as by improving capital stock, technology, managerial skills, entrepreneurial ability, brands, and access to markets (Thirwall 2000). Thus, increasing FCF should enhance the economic welfare of economic 
Table 1 Foreign capital flows to SSA

\begin{tabular}{lllllll}
\hline Year & 2008 & 2009 & 2010 & 2011 & 2012 & 2013 \\
\hline Foreign capital inflows & \$47billion & \$59.4billion & \$44.9billion & \$68.2billion & \$82.5billion & \$75.9billion \\
\hline Source: World Bank, World Development Indicators (2016) & & &
\end{tabular}

agents. Notwithstanding the rising trend in inflows, their effect on economic welfare is not well understood, especially in the context of SSA.

This study argues that the inflows affect welfare through FD, albeit with a lag. This is because they create additional demand for financial services, which in turn compels the financial sector to develop innovative products and ultimately improve how the financial system functions. The finance welfare hypothesis suggests that the level of FD affects the accumulation of both human and physical capital, which enhance economic welfare (Galor and Zeira 1993; Banerjee and Newman 1993; Kuznets 1955). Moreover, FCF spur the financial system to develop financial derivatives tailored for such inflows (Hausmann and Fernández-Arias 2000; Prasad 2007; Gruber and Kamin 2009). Thus, at this stage of financial system development economic welfare begins to improve (Greenwood and Jovanovic 1990), suggesting a potential feedback effect of FD on FCF.

FD seeks, among other things, to attract capital inflows that improve economic agents' welfare (Kai and Hamori 2009; Enowbi Batuo et al. 2010; Asongu 2013; Tita and Aziakpono 2016). Recent studies on SSA establish the effects of FD from financial globalization, financial depth, and financial efficiency on economic welfare (Kai and Hamori 2009; Enowbi Batuo et al. 2010; Asongu 2013; Tita and Aziakpono 2016). Nevertheless, these studies focus on GDP and related welfare indicators (income inequality) rather than specific welfare-enhancing variables that constitute an investment in human capital to improve economic welfare. Moreover, these studies consider direct links without any intermediaries between FD and economic welfare. A fall in the per-unit cost of operations at various levels of FD directly improves economic welfare.

In contrast, this study focuses on the interaction effect of FD and FCF on the intermediary factors that enhance economic welfare. I primarily contribute to the existing literature by ascertaining the interaction effect on the human economic welfare-enhancing indicators of education, health, consumption, and remittances. Education places economic agents in highly marketable positions for jobs and has a return that far outweighs its expenditures, among other effects (Kuznets 1955; Galor and Zeira 1993). Healthcare considerably determines the potential of an economic agent to secure gainful employment (Kleiman 1974; Newhouse 1977; Jacobs and Slans 2010). Consumption is a better measure of welfare than income-based indicators are. This is because it determines availability and accessibility, and denotes economic agents' health status while income-based indicators do not (World Bank 2016). Remittances help the poor to obtain the education and employment required to enhance economic welfare over time (Addison 2005; Russell et al. 1990). These benefits represent investments in human capital intended to enhance economic agents' welfare, though they are not prominent in the macroeconomics and international finance empirical literature. This study applies the principal component analysis (PCA) to create a single index, which I call the human economic welfare enhancement (HEWE) index, to investigate the role of FD in improving these welfare-enhancing indicators amidst increasing FCF to SSA. 
The rest of the study is structured as follows. Section 2 reviews the relevant literature. Section 3 outlines the methodology. Section 4 discusses the results and Section 5 concludes the study with some policy implications.

\section{Literature review}

From a theoretical perspective, FCF interact with domestic FD to enhance economic welfare. Welfare improves when a considerable level of FD induces FCF. These increasing inflows compel the financial system to develop financial derivatives that meet the demands of foreign and domestic firms. The interaction creates an inverted U-shaped relationship between FD and economic welfare (Greenwood and Jovanovic 1990). Greenwood and Jovanovic (1990) assert that sourcing funds from financial intermediaries comes with a cost, which is especially high when the intermediaries are in the infant stages of development in which only the relatively few rich members of the population can have savings and benefit from the financial services. The process widens the rich-poor income gap and causes economic welfare to deteriorate.

Over time, as economic growth continues, there is an increased demand from the real sectors for services from financial intermediaries. The increase in demand brings about competition, efficiency and a reduction in the transaction costs of financial intermediaries, thereby enabling the poor to access financial services to invest in human or physical capital. Therefore, the interaction increases the capital inflows and liquidity of the financial sector, decreases the cost of financial transactions, and increases domestic credit for investments in human and physical capital. Hence, investment in education and training improves the marketability of labor for gainful employment. On the other hand, investment in physical capital increases the capital-labor ratio, yielding higher productivity and income. ${ }^{1}$

The higher income due to the interaction effect may affect the health status of economic agents. On the one hand, nutritious foods, clean water, sanitation, education and medical care become more affordable and increases economic agents' life expectancy (Deaton 2003; Deaton 2004). Moreover, health and education outcomes may improve due to the medical and educational knowledge spillovers from this interaction (Bitzer and Kerekes 2008; Ang and Madsen 2013). Furthermore, interactions that affects the market for domestic firms' products may improve health and education conditions: the availability of pharmaceuticals, medical equipment and industry-tailored education reduces health complications and provides the entrepreneurial skills for job creation. Hence, economic agents' ability to afford good health care and education may reduce the rate of increase in government discretionary current expenditures on education and health, leading them to re-prioritize their recurrent spending in each fiscal period. This reduction may indicate improved economic welfare in the short run, but may have welfare-reducing consequences over time, when the effect of rate reduction outweighs the affordability effect.

Developing economies' competition for more capital inflows to enhance the interaction between capital inflows and FD to improve welfare may lead to tax incentives (Cleeve 2008). Tax incentives aiming to induce more inflows may reduce government revenue and consequently reduce its recurrent expenditure on education and health. In addition, rising rates of inflation may reduce government real expenditures on health and education. This usually occurs when prices rise such that the government rate of increase in recurring education and health expenditures fall short of that of inflation. In some cases, governments may prefer to increase expenditure on transportation networks and public security and neglect health and education (Gemmell et al. 2008; Herzer and Nunnenkamp, 2012). Thus, 
decreasing the government's current expenditure on education and health in the interaction could indicate a short-run welfare reduction.

Moreover, domestic firms' productivity in developing countries may fall: multinational enterprises (MNEs) have lower marginal cost due to the firm-specific advantage of providing unique services. This advantage increases the demand for foreign products while reducing the demand for domestic products and sending inefficient firms out of business (Aitken and Harrison 1999; Djankov and Hoekman 2000; Damijan et al. 2003). Thus, domestic firms have difficulty competing with foreign firms due to the latter's use of advanced technology and higher skilled-labor. This may result in a fall in domestic firms' revenue and the eventual collapse of some firms. The fall in revenue and collapse of firms may decrease economic agents' incomes. These agents find it difficult to afford the health and education services they need, thereby requiring an increase in the government's discretionary current expenditure to enhance economic welfare.

Furthermore, the pollution-haven hypothesis posits how cost-effective, but pollution-intensive firms, invests in developing countries with lower environmental standards (Eskeland and Harrison 2003). The education to ensure that environmental standards rise and that victims of pollution receive the appropriate health care require increasing government discretionary expenditure on health and education. Thus, the increased government spending in these areas provides social insurance against the adverse effects of the interaction between FCF and FD. Therefore, an increase in government spending on health and education may indicate an attempt to mitigate the welfare-reducing effects of this interaction (Rodrik 1998, p.997). Hence, the variability of income due to FCF and its interaction with FD correlates with economic welfare. The state of economic welfare highly determines the government's discretionary recurrent expenditures on health and education.

Moreover, Friedman's (1957) permanent-income hypothesis (PIH) suggests the relevance of the interaction effects to consumption and economic welfare. This hypothesis posits that an economic agent smooths his or her consumption over his or her lifetime based on the current and expected income. That is, agents will maintain a given level of consumption throughout their lifetimes, regardless of his or her current income, by saving the excess current income above the consumption level while an income below the given consumption level leads agents to borrow to finance spending. However, the agent's borrowing decision depends on the investments in human (education, training, and experience) and physical (shares, bonds, machines, equipment, or building) capital. These investments determine the agent's 'expected long-term average income' (permanent income) that guides the borrowing decision. Nevertheless, in low-savings economies, the interaction effects may augment domestic savings to meet the demand for domestic credit. Thus, the interaction of foreign capital and FD makes it highly possible to improve economic agents' incomes and to meet their borrowing demand. These funds facilitate the investments that warrant higher levels of consumption.

The interaction of FCF and FD potentially increases remittances received for welfare enhancement, which enhance welfare. FCF create an avenue for funds to move across borders through the economy's financial sector. The sector serves as a conduit for MNEs to facilitate the movement of funds and equipment from their host or other foreign countries to the recipient economies. The movement then necessitates a new or efficient channel to transmit funds to the recipients. The new or efficient means of funds transfer facilitate an increase in the remittances received from the domestic economic agents residing in these 
foreign countries. On the contrary, inefficient means to transfer funds may increase financial charges on remittances and negatively affect the remittances received. Thus, the interaction of capital inflows and FD may negatively affect the remittances received to enhance economic welfare. Notably, SSA has a relatively higher cost to receive remittances due to relatively smaller amount of FCF it receives relative to other regions. ${ }^{2}$

Empirically, Kappel (2010) suggests that an increase in government spending does not narrow the differences in economic welfare in low-income countries. However, he confirms the government spending and an effective stock market are drivers that reduce differences in economic welfare in high-income countries. Recent studies aim to establish the threshold effects of FD on income inequality (Kim and Lin 2011; Tan and Law 2012a, 2012b; Law et al. 2014). Kim and Lin (2011) establish the non-linear threshold effect of FD by using an instrumental variable threshold regression method to analyze panel data on developed and developing countries. Their results are consistent with Greenwood and Jovanovic's (1990) inverted U-shaped hypothesis. They suggest that below a threshold level of FD, the plight of the poor will worsen disproportionately. Nevertheless, this difficulty dissipates as a country reaches a threshold level of FD. Tan and Law (2012a, 2012b) also use the threshold effect approach, but find results that contradict Greenwood and Jovanovic's (1990) inverted U-shaped hypothesis. Law et al. (2014) suggest that the level of efficiency and effectiveness of institutions determine the extent to which FD narrows the differences in economic welfare. They conclude that without high institutional quality, financial intermediaries will not be able to reduce income inequality. However, these studies fail to account for investment in human capital as a principal driver that narrows income inequality as the financial system develops.

In the context of SSA's abundant natural resources, the region attracts FCF mainly due to its enhanced investment and business climate, improving macroeconomic conditions, privatization, preferred trade schemes, and reformed legal framework (Chea 2011). Furthermore, the opportunity to produce in sectors at a low cost relative to the U.S. and the E.U., low cost production for export under the African Growth and Opportunity Act (AGOA), and EU's Everything but Arms (EBA) policy make SSA an attractive destination for export-oriented investors (Mlachila and Takebe 2011). SSA developing economies saw six-fold increase in private capital inflows since 2000, to the tune of \$75 billion in 2007. Despite the financial crisis, which registered a net withdrawal of $\$ 562$ million in portfolio equity, private capital increased to $\$ 79.5$ billion in 2008 and then to $\$ 135$ billion in 2013 (WDI, 2015). The question that empirically remains unanswered is how economic welfare responds to foreign capital flows across borders.

Considerable cross-country empirical studies on the relationship between finance and welfare in SSA exists. These studies use income inequality as a measure of economic welfare, in which a decline in income inequality as finance increases denotes improved economic welfare. Prominent among these authors are Kai and Hamori (2009), who find that economic welfare in the form of rising income inequality decreases due to globalization. However, countries with some requisite levels of education tend to reap the full benefits of globalization. These countries balance their benefits with the negative effects of rising income inequality. Moreover, globalization tends to neutralize the effect of global financial depth on reducing income inequality in developing countries because it benefits the rich rather than the poor.

Enowbi Batuo et al. (2010) and Gries and Meierrieks (2010) suggest that FD reduces the differences in economic welfare between the rich and the poor due to a decline in income 
inequality. Moreover, Asongu (2013) reveals that though enhanced financial depth reduces income inequality, there is a positive relationship between financial efficiency and rising income inequality. He concludes that an efficient financial system does not improve the lives of the poor, but rather those of the rich. The rich tend to benefit from the large average loans size and deposits per capita in the course of FD due to their ability to provide collateral.

Conspicuously missing from this literature are studies of how the interaction of FD and FCF influences investment in human capital, which is a key driver that enhances welfare. In view of the general support for expenditures on education, health, household consumption, and remittances as a monetary measure of investment in economic welfare (Appendix 4), I first examine the effect of the interaction of FD and FCF on these individual variables. Then I use PCA to index them as a dependent variable to estimate the model. I subsequently analyze the effect of the interaction of FCF and FD on these welfare enhancing indicators and the index.

\section{Model, empirical strategy, and data Model specification}

To identify the interaction effects of FD and FCF in SSA, I follow the standard practice in the welfare finance literature and specify my model as in Eq. (1). The model expresses human economic welfare as an index constructed using PCA and comprising government expenditure on education and healthcare, household consumption expenditures, and remittances $^{3}$ as a function of FCF (a vector of official credit and foreign direct investment, FDI), the FD indicator, and the interaction between the two independent variables.

$$
\begin{aligned}
& H E W E_{i, t}=\beta_{c 1} F C F_{i, t}+\beta_{c 2} F C F_{i, t-1}+\delta_{c 1} F D_{i, t}+\delta_{c 2} F D_{i, t-1}+\rho_{c 1}\left(F C F_{i, t} * F D_{i, t}\right)_{i . t} \\
& +\rho_{c 2}\left(F C F_{i, t} * F D_{i, t}\right)_{i . t-1}+\phi_{c} X_{i, t}+\omega_{c} z_{i, t}+\varepsilon_{i, t}
\end{aligned}
$$

where $H E W E_{i, t}$ is the human economic welfare index in real per capita terms. $\beta_{c}, \delta_{c}, \rho_{c}$, and $\phi_{c}$ are the parameters of interest, with the subscript "c" denoting their lags. $\mathrm{c}=1$ denotes the level variable coefficient and $\mathrm{c}=2$ denotes the coefficient of its first lag. $F C F_{i, t}$ is FCF as a ratio of GDP. I introduce lags due to the theoretical supposition that the effects of macrofinancial variables are not always instantaneous. For example, not all components of FCF have an instant effect on FD and welfare; credit from foreign commercial banks should have an instant effect on banks' capital adequacy ratios and a contemporaneous effect on economic welfare through credit. The effect on the welfare occurs after some time elapses. Moreover, FDI may have both instant and later effects on economic welfare: while the transfer of skills from the inflows takes time to occur, economic welfare instantly improves through the creation of new jobs, though the inability of domestic firms to compete well with foreign firms may offset the gain from job creation. $F D_{i, t}$ is the FD indicator (domestic credit to the private sector; money supply) as a ratio of GDP, and $F C F_{i, t} * F D_{i, t}$ is the interaction term to establish whether FCF affect economic welfare as it interacts with FD. $X_{i, t}$ is a vector of control variables, which include inflation and trade as a ratio of GDP. Inflation intends to capture the effects of changes in general price levels on the economic welfare variable $\left(H E W E_{i, t}\right)$. The trade/GDP ratio indicates the extent of openness to international trade. $\omega_{c} z_{i, t}$ is the time dummy for the period under study (2000-2013) to capture the business cycle over the period and to mitigate possible cross-sectional dependence. All the variables are in natural logarithms. The error term $\varepsilon_{i, t}$ captures the unobservable shocks to the 
welfare index $\left(H E W E_{i, t}\right)$. The unobservable time-invariant (fixed effect) country-specific characteristics $\left(v_{i, t}\right)$ such as demographics and the observation-specific errors $\left(e_{i, t}\right)$ constitute the error term $\left(\varepsilon_{i, t}\right)$, specified as $\varepsilon_{i, t}=v_{i, t}+e_{i, t}$.

\section{Empirical strategy}

Identifying the parameters of the model in Eq. (1) is challenging. A notable identification challenge here is that of potential endogeneity, which when not treated well will result in biased estimates. For example, an improvement in $H E W E_{i, t}$, such as via remittances and education, which plausibly correlates with higher income, could make it possible for agents to acquire collateral and access more credit. Therefore, it follows that domestic credit to the private sector possibly correlates with the error term of the dependent variable $\left(H E W E_{i, t}\right)$. Furthermore, higher $H E W E_{i, t}$ denotes healthy, educated and well-skilled human capital prepared to meet the demands and standards of FCF such as FDI, and hence a possible correlation between FCF and the error term of $H E W E_{i, t}$. Moreover, an improved $H E W E_{i, t}$, such as through consumption, potentially increases trade volumes. Therefore, there exists a potential correlation between trade/GDP and the error term of the dependent variable $\left(H E W E_{i, t}\right)$. These possible correlations between the independent variables and the error term of the dependent variable could bias the parameter estimates.

To overcome this identification challenge, I propose the system GMM estimator, which unlike other estimators, permits the use of lags of the potential endogenous independent variables as instruments. I use these instruments due to the difficulty of finding appropriate instruments that mitigate endogeneity issues. Moreover, when the sample includes fewer years than countries, the system GMM best mitigates endogeneity issues. Furthermore, using the Sargan/Hansen test is important when applying Dynamic Panel Data estimators because such estimators are instrumental variable methods. Using the Sargan/Hansen test to test the validity of the instruments is paramount ex-post GMM estimation (Roodman 2006). Moreover, a test within the estimator ascertains the state of autocorrelation in the idiosyncratic error term $\left(\varepsilon_{i, t}\right)$. GMM estimation involving panel data test for autocorrelation has proven valid whenever researchers apply the Arellano-Bond test for autocorrelation. This test encompasses OLS and 2SLS provided that the regressors are not determined "ex-post" on the premise of future disturbances. However, this presupposition may be nullified in the fixed effect or the within-group regressions if $\mathrm{T}$ is small (Roodman 2006). In addition, GMM applies first differencing to transform Eq. (2), which helps to avoid inconsistency due to the weak instruments associated with fixed-effects instrumental variables (IV) estimators and to deal with possible correlation between the fixed effect and lagged dependent variable and other regressors such as the FD indicator and inflation. This is because it removes the time-invariant fixed-effect component from the model. Instrumenting the first-differenced lagged dependent variable with its past levels helps address the issue of autocorrelation.

Based on the system GMM estimator, I re-specify the empirical model (Eq. 1) as a Dynamic model.

$$
\begin{aligned}
& H E W E_{i, t}=\alpha_{c} H E W E_{i, t-1}+\beta_{c 1} F C F_{i, t}+\beta_{c 2} F C F_{i, t-1}+\delta_{c 1} F D_{i, t}+\delta_{c 2} F D_{i, t-1} \\
& +\rho_{c 1}\left(F C F_{i, t} * F D_{i, t}\right)_{i . t}+\rho_{c 2}\left(F C F_{i, t} * F D_{i, t}\right)_{i . t-1}+\phi_{c} X_{i, t}+\omega_{c} z_{i, t}+\varepsilon_{i, t}
\end{aligned}
$$

where $H E W E_{i, t-1}$ is the lag of the dependent variable. The remaining variables are the same as those in Eq. (1). I expect that foreign capital inflows $\left(F C F_{i, t}\right)$, being FDI or official credit, will be positive, which denotes a positive impact on real welfare-enhancement due to the transfer of skills and capital associated with such inflows. FDI for instance may shift 
government expenditure to provide social insurance against external risk (Rodrik 1998, p.997; Gemmell et al. 2008). However, the extent to which domestic firms will survive competition due to FDI will determine the feasibility of this positive expectation. Moreover, incentives like tax holidays or lower taxes intended to induce FCF such as FDI eventually reduces government revenue, which may affect the composition of its expenditure and decrease recurrent expenditures on education, health and other social expenditures (see Herzer and Nunnenkamp 2012). Further, the redirection of government expenditure to public safety and transportation to make an economy more FDI-friendly may reduce expenditure on education and health, thereby reducing welfare (Figlio and Blonigen 2000). I expect that the FD indicator $\left(F D_{i, t}\right)$, being domestic credit or the money supply, will be positive, in agreement with the theoretical supposition that it improves GDP by meeting the demands of an economy and thus provide the poor with the finance required to invest in education. The interaction term $\left(F C F_{i, t} * F D_{i, t}\right)$ and its lag help to establish how FCF affect welfare at the current level of SSA's FD. FCF can take the form of foreign banks. Hence, an open economy with well-functioning legal institutions that ensure contract enforcement can induce such inflows. Its lag could have a similar effect because FD is a process. Thus, the level of FD highly determines how foreign financiers invest in the domestic economy to influence economic welfare. However, the difficulty of enforcing contracts and applying inhumane strategies to recover due loans may negatively affect income, consumption and economic welfare. Thus, the lag of the interaction term may affect economic welfare. Moreover, increasing general price levels may lead to negative coefficient on the interaction term $\left(F C F_{i, t} * F D_{i, t}\right)$ as the cost of borrowing tends to rise in this situation. Therefore, I expect the coefficient of $\left(F C F_{i, t}\right.$ $\left.* F D_{i, t}\right)$ and its lag to take either a positive or negative sign because the level of FD can determine whether FCF have a negative or positive impact on the welfare enhancing variables.

\section{Data and variables}

The sample consists of 23 SSA countries $(N=23)^{4}$ for the sample period of 2000-2013 $(\mathrm{T}=14)$ based on data availability. I collected most data from the WDI (2015).

First, I created the HEWE index using PCA due to the strong correlation among the variables within each index (Table 6, Appendix 1). The HEWE index consists of remittances per capita (lnrempc), household consumption expenditure per capita (lnhcepc), government expenditure on health per capita (lngovhepc), and government expenditure on education per capita (lngoveepc), all as natural logarithms. The HEWE1 index created for HEWE explains $75 \%$ of the total variations in the original data. This denotes a reduction of the HEWE dimension to a quarter, though it preserves $75 \%$ of the information in the data. Moreover, HEWE1 is the only component with eigenvalues above unity and the only index with all constituent indicators scoring above the 0.3 or higher benchmark to determine the level of significance. Therefore, HEWE1 significantly represents the four chosen indicators and thus, the dependent variable for the estimable Eq. (2).

Second, due to limited data availability for many SSA countries, I use domestic credit and the money supply as proxies for FD. Credit to the private sector as a ratio of GDP is the most well known proxy in the literature due to its peculiar features. This variable has a strong correlation with income levels, ranging above $103 \%$ in high-income countries, four times higher than that of low-income countries (Levine and Zervos 1998). Moreover, it supports long-run economic growth and highly correlates with poverty 
reduction (World Bank 2012). In addition, the ratio of M2 to GDP measures the extent of monetization in an economic system. ${ }^{5}$ These two variables fall short in determining access to bank finance, non-performing loans, and the extent of bank intermediation. Nevertheless, they can help clarify how FCF enhance economic welfare.

Third, $F C F_{i, t}$ is FCF. It indicates either FDI (the proxy for private capital inflows) or official credit inflows (World Bank, IMF, IBRD, IFC), expressed as a ratio of GDP. It measures the size of external debt relative to economic output. I obtain the interaction term $\left(F C F_{i, t} * F D_{i, t}\right)$ as the product of the FCF indicator (FDI or official credit) as a ratio of GDP and the FD indicator (domestic credit to the private sector or money supply) as ratio of GDP. I include this term in the model to assess how FCF enhance human economic welfare at a particular state of FD (Adeniyi et al. 2015). I focus on FDI or official credit inflow as an indicator of FCF because SSA economies uniquely identify FDI and official credit as the major sources of financing for domestic activities (Delechat et al., 2009). Official credit constitutes the largest proportion of FCF into SSA, followed by FDI (World Bank, 2015). Both official credit and FDI potentially affect liquidity in SSA economies. Due to the higher proportion and consistency of FDI and official credit flow compared to the other components of foreign capital, they potentially improve liquidity, income and savings, and enhance household consumption, firms' revenue, and the financial sector's turnover. Similarly, servicing official credit or foreign investment outflow could greatly affect the money supply and domestic credit because a government potentially borrows from the domestic credit market to smoothen its expenditure, thereby crowding-out the private sector. Firms face liquidity challenges as outflow occurs and the domestic currency tends to depreciate due to higher demand for foreign currency resulting from the outflow of funds. Thus, I expect that FDI or official credit will affect economic welfare in SSA compared to the impact of portfolio equity or private creditors. The model also includes an inflation variable, which reflects the annual percentage change in the cost to the average consumer for acquiring a basket of goods and services that may be fixed or change at specified intervals, such as yearly. Studies generally use the Laspeyres formula. Finally, I include trade as a percentage of GDP as a proxy for trade openness. It is the sum of the exports and imports of goods and services measured as a share of GDP.

\section{Empirical results and analysis}

\section{Effect of FCF and FD on economic welfare}

I use FDI and official credit (OFFCR) as proxies for FCF, and domestic credit to the private sector (DOMCR) and money supply (MS) as proxies for FD, each as a ratio of GDP. The results in Tables 2 and 3 below show the parameter estimates of the variables of interest: the interaction terms (FDI*DOMCR, FDI*MS, OFFCR*DOMCR and OFFCR*MS) and their lags.

The statistical significance in Table 2 suggests a possible total effect of FDI on HEWE. FDI has a direct partial effect $(\beta \mathrm{c} 1)$ and.

an indirect partial effect through FD (the product of $\rho \mathrm{c} 1$ and mean FD). The total effect from Eq. 2 is $\partial H E W E i, \partial F C F i, t=\beta c 1 /+(\rho c 1 x$ mean of FD $i, t)$, where FCF and FD are FDI and DOMCR, respectively, in Table 2, Model III and FCF and FD are FDI and MS, respectively, in Table 2, Model V. Table 4 presents these effects. 
Table 2 Dynamic panel data estimation, one-step system GMM: Interaction effect of FDI and FD on HEWE

\begin{tabular}{|c|c|c|c|c|c|}
\hline \multicolumn{6}{|l|}{ HEWE } \\
\hline Regressors & Model I & Model II & Model III & Model IV & Model V \\
\hline L1 HEWE & $0.987^{* * *}(0.037)$ & $1.044^{* * *}(0.064)$ & $1.028^{* * *}(0.041)$ & $1.054^{* * *(0.052)}$ & $1.027^{* * *}(0.044)$ \\
\hline FDI & $-2.04^{* *}(0.620)$ & $-1.99^{* *}(0.647)$ & $-13.321^{* * *}(3.461)$ & $-2.023^{* *}(0.782)$ & $-23.762^{* * *}(7.967)$ \\
\hline L1 FDI & $2.44^{* *}(0.736)$ & $2.513^{* *}(0.882)$ & $14.585^{* * *}(3.282)$ & $2.793^{* *}(0.928)$ & $21.112^{* * *(3.378)}$ \\
\hline DOMCR & - & $0.153(0.102)$ & $0.045(0.095)$ & - & - \\
\hline L1 DOMCR & - & $-0.247^{*}(0.128)$ & $-0.129(0.098)$ & - & - \\
\hline MS & - & - & - & $0.285^{* *}(0.097)$ & $0.093(0.156)$ \\
\hline L1 MS & - & - & - & $-0.514^{* *}(0.160)$ & $-0.362^{* *}(0.177)$ \\
\hline $\mathrm{FDI}$ *DOMCR & - & - & $4.953^{* * *}(1.373)$ & - & - \\
\hline L1 FDI*DOMCR & - & - & $-5.617^{* * *}(1.393)$ & - & - \\
\hline $\mathrm{FDI}{ }^{*} \mathrm{MS}$ & - & - & - & - & $6.634^{* * *}(2.192)$ \\
\hline L1 FDI*MS & - & - & - & - & $-5.952^{* * *}(0.982)$ \\
\hline Openness & $0.088(0.154)$ & $0.035(0.164)$ & $0.142(0.228)$ & $0.071(0.158)$ & $0.211(0.233)$ \\
\hline Inflation & $-0.014^{* * *}(0.002)$ & $-0.015^{* * *}(0.002)$ & $-0.015^{* * *}(0.003)$ & $-0.014^{* * *}(0.002)$ & $-0.016^{* * *}(0.003)$ \\
\hline AR 1 & 0.092 & 0.109 & 0.003 & 0.113 & 0.008 \\
\hline AR 2 & 0.158 & 0.214 & 0.539 & 0.204 & 0.356 \\
\hline Hansen & 0.10 & 0.258 & 0.918 & 0.242 & 0.312 \\
\hline
\end{tabular}

Note: Values in parenthesis denote the robust standard errors of respective estimates. ${ }^{* *} \mathrm{p}<0.01(1 \%),{ }^{* *} \mathrm{p}<0.05(5 \%)$ and ${ }^{*} p<0.10(10 \%)$ denote the level of significance. Time dummies from 2000 to 2013 not reported. Number of observation: $\mathrm{N}=23 ; \mathrm{T}=14$. FDI is used as indicator for foreign capital inflows (FCF); Domestic Credit (DOMCR) and Money Supply (MS) are used as indicators for Financial Development (FD) in models (II, III) and (IV, V) respectively

Moreover, I consider portfolio inflows and private creditors, despite their "true zeros" values in the data for some of the sample countries. I measured these variables following the same process to measure FDI and official credit. The effect of portfolio inflow on human economic welfare was statistically insignificant; its interaction with FD had statistically insignificant effect on welfare enhancement (Table 12 in Appendix 5). I find similar results for private credit inflow: neither private credit nor its interaction with domestic credit had a statistically significant effect on welfare enhancement (Table 13 in Appendix 5).

Given the significant correlation among some of the components of FCF (FDI, portfolio equity, private credit and official credit inflows: Appendix 6 Table 14), I conducted PCA (Appendix 6 Table 15) to ascertain the interaction effect of the combined components of FCF and FD on welfare enhancement. The first (FCF1) and second (FCF2) principal components explained $34.05 \%$ and $29.71 \%$ of the total variations in FCF, with eigenvalues of 1.36191 and 1.18846, respectively (Table 15 in Appendix 6). Portfolio and FDI returned the highest (0.6796) and second highest (0.4591) highest eigenvectors, in absolute terms, of FCF1. For FCF2, official credit and FDI registered the highest (0.7056) and second highest (0.5710) eigenvectors in absolute terms. The eigenvalues of FC3 and FCF4 are less than one. I thus use FCF1, which has the highest eigenvector (0.3746) among the minimum eigenvectors of the components.

FCF1's interaction with FD are consistent with that of FDI's interaction with FD (Table 16 in Appendix 6). The level interaction term of FCF1 and FD is statistically significant and positive, while its lag is negative and statistically significant. Moreover, the partial indirect effects of FCF1 on economic welfare are positive, conditional on the level of FD (DOMCR (0.195) and MS (0.569); Table 17 in Appendix 6). These results 
Table 3 Dynamic panel data estimation, one-step system GMM: Interaction effect of OFFCR and FD on HEWE

\begin{tabular}{llllll}
\hline HEWE & \multicolumn{7}{l}{$l$} & \\
\hline Regressors & Model I & Model II & Model III & Model IV & Model V \\
\hline L1 HEWE & $1.012^{* * *}(0.057)$ & $1.073^{* * *}(0.094)$ & $0.918^{* * *}(0.174)$ & $0.937^{* * *}(0.123)$ & $0.943^{* * *}(0.107)$ \\
OFFCR & $-0.010(0.007)$ & $-0.011(0.009)$ & $0.042(0.049)$ & $-0.010(0.011)$ & $-0.068(0.576)$ \\
L1 OFFCR & $0.010(0.010)$ & $0.012(0.011)$ & $-0.007(0.39)$ & $0.013^{*}(0.007)$ & $0.077(0.396)$ \\
DOMCR & - & $0.129(0.104)$ & $0.346^{*}(0.188)$ & - & - \\
L1 DOMCR & - & $-0.260(0.162)$ & $-0.253^{* *}(0.123)$ & - & - \\
MS & - & - & - & $0.377^{* * *}(0.109)$ & $0.387^{* * *(0.127)}$ \\
L1 MS & - & - & - & $-0.255(0.352)$ & $-0.283(0.260)$ \\
OFFCR*DOMCR & - & - & $-0.016(0.015)$ & - & - \\
L1 OFFCR*DOMCR & - & - & $0.007(0.014)$ & - & - \\
OFFCR*MS & - & - & - & - & $0.016(0.164)$ \\
L1 OFFCR*MS & - & - & - & - & $-0.019(0.115)$ \\
Openness & $0.017(0.145)$ & $-0.023(0.179)$ & $0.150(0.290)$ & $0.084(0.150)$ & $0.081(0.122)$ \\
Inflation & $-.014^{* * *}(0.003)$ & $-0.015^{* * *}(0.002)$ & $0.002(0.005)$ & $-0.001(0.004)$ & $-0.001(0.004)$ \\
AR 1 & 0.158 & 0.178 & 0.062 & 0.079 & 0.073 \\
AR 2 & 0.261 & 0.292 & 0.295 & 0.274 & 0.121 \\
Hansen & 0.035 & 0.166 & 0.276 & 0.124 & 0.221 \\
\hline
\end{tabular}

Note: Values in parenthesis denote the robust standard errors of respective estimates. ${ }^{* * *} \mathrm{p}<0.01(1 \%),{ }^{* *} \mathrm{p}<0.05(5 \%)$ and ${ }^{*} p<0.10(10 \%)$ denote the level of significance. Time dummies from 2000 to 2013 not reported. Number of observations: $N=23 ; T=14$. Official Credit (OFFCR) is used as indicator for Foreign Capital Inflows (FCF); Domestic Credit (DOMCR) and Money Supply (MS) are used as indicators for Financial Development (FD) in models (II, III) and (IV, V) respectively. The use of financial development's proxies in separate models stems from their high correlation, which may bias the parameter estimates; the same applies to the proxies of foreign capital inflows (Appendix 8 in Table 3). Models III and V in both Tables are the choice models because they include the interaction terms, which are the variables of interest

are also consistent with those for FDI. Hence, I expect its results to follow the same pattern as that of FDI as an indicator of FCF. However, due to the prevalence of "true zeros" in the portfolio equity and private credit data, I use FDI and official credit as proxies of FCF for the analysis (Tables 2, 3 and 4).

\section{Discussion}

Models III and V of Table 2 suggest that DOMCR does not enhance economic welfare: both the level and lag of DOMCR are statistically insignificant. However, the level of FDI negatively affects HEWE, indicating the partial direct effect of FDI on economic

Table 4 Effect of FDI on HEWE, conditional on FD

\begin{tabular}{|c|c|c|c|c|}
\hline & \multicolumn{2}{|c|}{ Domestic Credit } & \multicolumn{2}{|c|}{ Money Supply } \\
\hline & Level & Lag & Level & Lag \\
\hline $\begin{array}{l}\text { Partial indirect effect of FDI on HEWE: conditional on the mean of } \\
\text { Financial Development }\end{array}$ & 13.496 & -15.306 & 22.363 & -20.064 \\
\hline Interactive effect of FDI and Financial Development on HEWE & 4.953 & -5.617 & 6.634 & -5.952 \\
\hline Partial direct effect of FDI on HEWE & -13.321 & 14.585 & -23.762 & 21.112 \\
\hline Total effect of FDI on HEWE & 0.175 & -0.721 & -1.398 & 1.048 \\
\hline
\end{tabular}

$\partial H E W E_{i, t} / \partial F C F_{i, t}=\beta_{c 1}+\left(\rho_{c 1} x\right.$ mean of $\left.F D_{i, t}\right) ; F C F$ is FDI and FD is DOMCR or MS. Mean of DOMCR $=2.725 ;$ Mean of $M S=3.371$. Values are significant at $1 \%$ level 
welfare that occurs in the same year. First, household consumption reduces as FDI increases: it is difficult for domestic firms to compete with foreign firms due to the use of advanced technology, higher skilled labor, and relatively low marginal costs. These advantages over SSA's domestic firms reduce their revenue and the eventual failure of the inefficient domestic firms. This in turn negatively affects household income, decreases consumption, and reduces economic welfare. In addition, governments increase their expenditures on transportation networks and public security to induce FDI at the expense of recurrent expenditures on health and education (Gemmell et al. 2008; Nagel et. al., 2015), which harms economic welfare. FDI's negative effect significantly affects the consumption, education and health components of HEWE when DOMCR is the proxy for FD (Table 9 in Appendix 3). On the other hand, its negative effect significantly affects the health and education components when MS is the proxy for FD (Table 10 in Appendix 3). Hence, FDI's direct partial effect is economic welfare reducing in the current period (Table 4).

However, FDI's total effect is significantly positive $(0.175)$ at the $1 \%$ level according to the mean domestic credit (Table 4) because the partial indirect effect of FDI on economic welfare is significantly positive (13.496) and outweighs its negative partial direct effect $(-13.321)$. The positive effects may be possibly results from the creation of additional employment, funds to augment inadequate domestic savings to meet domestic credit demands, the acquisition of credit to increase human and capital investments, higher incomes that increase household consumption, and increasing current government expenditure on education and health as social insurance to mitigate the undesirable effects of FDI. Moreover, remittances may potentially increase due to the relatively cheaper cost of funds transfer in the destination of the inflows. Therefore, the total effect of FDI is economic welfare enhancing in the current period. However, when I evaluate the total effect of FDI on HEWE in terms of the mean MS, its negative effect outweighs its positive effect in the current period (Table 4). Hence, the increased MS due to FDI has economic welfare-reducing effects in SSA.

On the contrary, the positive effect of the lag of FDI on HEWE denotes its partial direct effect on economic welfare after the first period (14.585 and 21.112 of Tables 2 and 4). This result is possibly due to additional employment, skills transfer, and the ability of some domestic firms to re-strategize to compete effectively with foreign firms after the first period. Consequently, household income improves and consumption increases, governments increase their recurrent expenditures on education and health to enhance the deteriorating welfare in the first period. FDI's partial direct positive effect significantly affects the health, education and consumption components of HEWE when I use either DOMCR or MS as the proxy for FD (Tables 9 and 10 in Appendix 3). However, the total effect is negative $(-0.721)$ at the $1 \%$ significance level when I evaluate it in terms of the mean DOMCR. This negative result suggests that the partial indirect effect of the lag, conditional on the level of DOMCR development, is welfare reducing (-15.306). The total negative effect possibly results from the welfare-reducing methods the financial sector employs to recover credits granted after one year, the more careful selection of borrowers to minimize adverse selection situations, adherence to strict monitoring of contract execution to minimize moral hazard, and opting for credit portfolios 
that yield higher returns at the expense of welfare-enhancing products. These actions may decrease household consumption and worsen health conditions, thereby making government expenditure disproportionately small relative to the higher cost of deteriorating health conditions and that households may leave private schools to join the public schools. This potentially makes government's current expenditure on education disproportionately small relative to the cost (new teachers, additional salary, additional supervisors, more teaching materials, and textbooks) associated with the growing demand. Hence, the negative effect outweighs the positive effect and leaves a negative total effect on economic welfare. On the other hand, the total effect of the lag of FDI is positive (1.048) at the 1\% significance level in terms of the mean MS: its partial direct effect on HEWE is significantly positive (21.112) and its partial indirect effect is significantly negative $(-20.064)$. This result suggests that the positive effect outweighs the negative effect and enhances economic welfare after the first period.

The positive coefficient of the level FDI*DOMCR and FDI*MS suggest that FDI positively affects its contemporaneous HEWE at the current state of SSA's financial development (Table 4). These welfare-enhancing benefits emanate from the introduction of new or modified financial derivatives intended to attract more FDIs, increase credit to the private sector, and improve the monetization of the economy (Tan and Law 2012a, 2012b). Moreover, efficiency becomes a product of the competition associated with the FDI, which leads to cost minimization in the acquisition of information, contract enforcement, and financial transaction in the financial system. This state of FD enables economic agents to borrow to smoothen their consumption on the bases of their expected long-term average incomes. Hence, household consumption increases and enhances economic welfare. Moreover, investment in human capital (education, training, skills, and experience) and physical capital (shares, bonds, machines, factory buildings) determines the expected long-term average income. Governments tend to increase its recurrent expenditures on education to provide adequate knowledge to sustain the pattern of an economic agent's lifetime consumption, develop safety measures for firms that meet international safety standards, and training to impart skills that meet the international standards. Governments also increase their recurrent expenditures on health to address the deterioration in general health due to the higher real cost of healthcare due to inflation and the stress of longer hours of work for a relatively higher income, resulting in less rest, less social interaction and unhealthy eating habits (junk food and alcoholism) (Nagel et al. 2015). Hence, the benefits of FDI for human economic welfare at the current state of financial development tend to outweigh any negative effect. The interaction significantly affects the consumption, health, and education components of the HEWE when I use DOMCR as the proxy for FD. When I use MS as the proxy for FD, the effect is significant on the health, education, and remittances components of HEWE (Tables 9 and 10 in Appendix 3).

However, the lag of the interaction term's coefficient is significantly negative, suggesting that given the short-term maturity in financial derivatives tailored to households, the negative effects appear one year down the line of the interaction term on human economic welfare (Clarke et al. 2006). This welfare-reducing condition 
occurs mostly due to the high default rate of SSA households (Andrianova et al. 2011). This plausibly emanates from adverse selection, moral hazard, and the difficulty of enforcing loan contracts. These challenges caution banks to lend little while using stress-related strategies to recover financial assets in loans and related products (Andrianova et al. 2011). Furthermore, these conditions influence the financial system to trade welfare-related products for short-term lucrative investment portfolios to continue attracting more FCF. This eventually reduces consumption and economic welfare. Furthermore, a government's attempt to stabilize FDI inflows results in FDI-inducing expenditures at the expense of recurrent expenditures on education and health. Ghana, for instance, increased its spending on road network development and strengthening the security and legal system to induce more FDI and to develop the financial system in 2015 and 2016. This policy direction was at the expense of recurrent expenditures on education and health, notably the non-payment of $\$ 24,139,747.24$ for feeding grants to 134,300 senior high school students, resulting in an indefinite suspension of the re-opening of some schools, ${ }^{6}$ and the non-payment of National Health Insurance Scheme (NHIS) claims to providers, resulting in the withdrawal and threat of withdrawal of services by some healthcare providers. ${ }^{7}$ The economic welfare-reducing effects were very high in 2017, thereby compelling the government to pay for all claims in the 2017 fiscal year to enhance welfare. Furthermore, the interaction negatively affects remittances: FDI does not plausibly come from countries that host domestic economic agents, and these countries have relatively high cost to transfer money. The negative effect of the interaction significantly affects the consumption, education, health and remittances of the HEWE components (Tables 9 and 10 in Appendix 3).

The positive effect of the interaction term and the negative effect of its lag on HEWE further suggest that as more FDI flows into SSA, underdeveloped financial systems possibly offer both efficient and inefficient financial derivatives, which enhance welfare in the current year. However, the financial system innovates its financial derivatives in tune with FCF in the course of its development and tailors its products to suit lucrative short-term returns to maintain its profit margins due to rising bad debts from inefficient financial derivatives. ${ }^{8}$ In this case, the financial system uses stress-related strategies to recover loans that are likely to be bad due to the legal system's lax enforcement (Nissanke and Aryeetey 2008). The significantly negative coefficient of the interaction term's first lag in Models III and V denote this welfare-reducing situation.

The interaction's coefficient in Model V of Table 1, where MS is the proxy for FD is as significant as that of Model III; nevertheless, the coefficient of the lag of MS in Model V is negative and statistically significant (Tables 2 and 4). This exceptional result in Model V suggests that the MS in the previous year (L1 MS) has a negative effect on the current year HEWE. This suggests that MS tends to negatively affect HEWE after one year. Thus, productivity falls short of the increase in MS, and this gap eventually results in rising general price levels, and higher cost of living reduces real consumption, government education and health expenditures, and effects of remittances.

Official credit (OFFCR) and DOMCR are the proxies for FCF and FD, respectively, in Model III of Table 3. DOMCR's coefficient is positive and statistically 
significant, but its lag is significantly negative. These results suggest that liquidity in the financial system improves due to OFFCR, which enhances HEWE through DOMCR. DOMCR positively and significantly affects the consumption, education, and health components of HEWE (Table 11 in Appendix 3). Nevertheless, the influence of its lag on HEWE is negative and significant. These results support Clarke et al.'s (2006) hypothesis of widening income inequality as financial development proceeds. Though DOMCR's lag has an insignificant effect on the individual components of HEWE, it significantly affects the HEWE index (Table 11 in Appendix 3). Therefore, the results in Model III of Table 3 suggest that domestic credit supports economic welfare enhancing activities as new official credit flows into SSA. These inflows, among other things, improve financial derivatives to increase credit and monetize the economy. Nevertheless, the negative effect of the previous year's DOMCR on current welfare is plausibly due to the haste among financial institutions to issue new and improved financial derivatives in the current years in their attempt to capture a considerable share of the market. However, banks may not thoroughly think through a supposedly new and improved financial derivative or properly analyze their risks before selling them to economic agents. These risks, along with the laxity associated with risk assessment and monitoring of loans in current years tend to reduce investment in welfare-enhancing activities after one year (Ocaya 2012).

Model V, which also uses official credit as a proxy for FCF and MS as the proxy for FD have equally positively statistically significant coefficients for its level of MS. The basic difference between Models III and V is that the lag in FD of Model $\mathrm{V}$ is statistically insignificant, while that of the former is statistically significant. Nevertheless, FD has a consistent and positive impact on HEWE when official credit is the main source of FCF because the increased money supply, which tends to improve the monetization of the economy, positively affect human economic welfare.

\section{Impact of the interaction effect of FCF and FD on economic welfare}

I use Models III and V of Table 2 to compute the predicted impact of FDI on economic welfare. These models use domestic credit and money supply as a measure of financial development, respectively. All variables are in natural logarithms. A partial derivative of each model gives the predicted impact when I take the derivative with respect to the interaction of FDI with financial development $\left(F C F_{i, t} * F D_{i}\right.$, $\left.{ }_{t}\right)_{i . t}$. The significant coefficient on $F C F_{i, t} * F D_{i, t}$ is $\left(\rho_{c 1}\right)$ for each model. Hence, $\rho_{c 1} *\left(\text { meanFCF }_{i, t} * \text { meanFD }_{i, t}\right)_{i . t}$ gives the predicted mean impact of FDI on economic welfare at various stages of financial development. I illustrate the results for these predictions in Figs. (1) and (2) for Models III and V of Table 1, respectively (Figs. 1 and 2 in Appendix 2).

The predicted ranges for the impact of FDI on economic welfare range from 0.005 to 1.2 and 0.008 to 2.3 in Figs. (1) and (2), respectively. Burundi registers the lowest impact and Liberia registers the highest impact in each range. These results indicate that FDI inflows to Burundi and Liberia, due to financial development, enhanced economic welfare by $0.005 \%$ and $1.2 \%$, respectively. These results 
suggest that Liberia's household consumption and remittances improved more than they did in Burundi when FDI inflows increased due to improved financial development. Moreover, Liberia may enhance economic welfare by increasing its current expenditures on health and education to mitigate any effects of FDI that may reduce welfare (Rodrik 1998, p.997). Nevertheless, Ghana's 0.25 and South Africa's 0.20 (Fig. 1) results do not necessarily suggest that the amount of FDI inflows are higher in aggregate terms in Ghana than in South Africa; rather, Ghana's economic welfare is more sensitive to FDI inflows due to financial development than that in South Africa. The same analogy applies to Burundi and Liberia. Burundi and Kenya in the low-income economies of SSA were highly insensitive to the interaction effect of FDI and financial development on economic welfare. However, the remaining countries in this income category were equally sensitive to the effect on average as the countries in the lower-middle income group (Cameroon, Cote d'Ivoire, Nigeria, Lesotho, and Swaziland) and upper-middle income (Botswana and South Africa). Liberia (1.2\%) and Seychelles (1.1\%) in the low and upper-middle income economies were the most sensitive within their income categories.

\section{Conclusion}

The existing literature provides two main motivations for this study: the conduit by which FD transforms FCF into effects on economic welfare and the indicators for assessing improvements in welfare, which are GDP-based, though not all components of GDP have direct welfare enhancing effects. I apply the PCA method to create a single index, which I call the HEWE index; it consists of four direct welfare-enhancing indicators (education, health, household consumption and remittance received) without indirect welfare variables (like per capita GDP) as the conduit by which welfare improves. Thus, a decline in income inequality (a measure of improved welfare) may result from the favorable effect of FD, FCF, or their interaction with HEWE. Therefore, I investigate the role of FD in improving this direct welfare-enhancing index in the presence of FCF in SSA.

I employ the system GMM estimator to consider two cases of FCF and FD: the first in which the main source of FCF is either FDI or official credit, and the second in which FD takes the form of domestic credit to the private sector or the MS. Both the MS and domestic credit have significantly positive direct effects on economic welfare when official credit is the source of FCF. However, the effect of domestic credit on the welfare becomes negative after one year. Contrary to the effect of FD, the direct effect of official credit on welfare is statistically insignificant.

On the other hand, when FDI is the source of FCF, FD (domestic credit or money supply) has a statistically insignificant direct effect on economic welfare. However, the effect of FDI on welfare is statistically significant at all conventional levels: the partial indirect effect of its level on the welfare, which is conditional on the level of FD, is significantly positive; and the partial indirect effect of its lag on the welfare conditional on the level of FD, is significantly negative. These results are consistent with its total effect when I evaluate the mean domestic credit: the total effect of its level is significantly positive on economic welfare in the current period, while the total effect of its lag is significantly negative. These results are consistent with the level and lag interaction term coefficients: the interaction term 
of FDI and FD (domestic credit or money supply) is significantly positive in the current period, while this effect becomes negative after one year.

In conclusion, this study reveals the interaction effect between FDI and financial development on economic welfare. It further confirms that FDI affects economic welfare through credit to the private sector and the money supply positively at first, but become negative after one year. Additionally, the magnitude of its indirect effect on economic welfare, conditional on domestic credit to the private sector, is greater than that of its direct effect on welfare. Moreover, the magnitude of its indirect effect on welfare, conditional on the money supply, is less than that of its direct effct. Hence, the interaction improves the magnitude of the effect of domestic credit, and it decreases the magnitude of the effect of the money supply to enhance economic welfare compared to the direct effect of FDI on welfare. Thus, without financial development, FDI inflows rarely produce the desired welfare-enhancing results. I also establish that interaction between official credit and financial development has no effect on economic welfare. Though its inflow improves domestic credit, it becomes negative after one year. The consistent negative effects after one year possibly stem from financial intermediaries' attempt to minimize risk and modify their target markets to minimize the effects of adverse selection and moral hazard in the first period. Additionally, the relatively high levels of inflation affect the real incomes and consumprion levels of economic agents in SSA. The negative effects could dissipate if SSA economies consider an intentional and balanced approach to induce FDI to the health and education sectors, encourage cost efficiency to make such services accessible to the SSA's population, and adhere to inflation-related policies that enhance consumption and economic welfare.

\section{Endnotes}

${ }^{1}$ Kuznets' (1955) Migrants unexplained ability to educate the new generation to acquire the necessary skills required to get gainful employment as industrialization takes off that tends to narrow income inequality as the new generation, offspring of the migrants, get higher paid jobs.

${ }^{2}$ (www.odi.org/remittances-africa; http://blogs.worldbank.org/psd/how-can-we-cutthehigh-costs-of-remittancesto-africa )

${ }^{3}$ See Appendix 4 for elaborate discussion on the choice of variables comprising the HEWE index.

${ }^{4}$ Benin, Botswana, Burkina Faso, Burundi, Cameroon, Cote d'Ivoire, Gambia, Ghana, Guinea, Kenya, Lesotho, Liberia, Malawi, Mozambique, Nigeria, Senegal, Seychelles, Sierra Leone, South Africa, Swaziland, Tanzania, Togo and Uganda.

${ }^{5}$ FSDI@worldbank.org

${ }^{6}$ https://www.ghanaweb.com/GhanaHomePage/NewsArchive/Over-GHC124-millionreleased-to-pay-Free-SHS-grant-teacher-trainee-allowances-656068\#

${ }^{7}$ http://citifmonline.com/2017/02/12/well-pay-insurance-claims-soon-nhia/

${ }^{8}$ Sub-Saharan Africa Banking Review (2014). A review of the 2014 academic year (ey.com).

${ }^{9}$ See also Clifford et al. (2010) and Nordhaus and Tobin (1973)

${ }^{10}$ Kuznets Simon. "National Income 1929-1932". 73rd U.S. Congress, 2nd Session, Senate Document No. 124,7 accessed August 2, 2010.

${ }^{11}$ Kuznets Simon. How to Judge Quality" New Republic, October 20,1962,29. 


\section{Appendix 1}

Table 5 Correlation test for HEWE components

\begin{tabular}{lllll}
\hline & Health & Education & Consumption & Remittances \\
\hline Health & 1.000 & & & \\
Education & $0.9178(0.0000)$ & 1.000 & & \\
Consumption & $0.8641(0.0000)$ & $0.8754(0.0000)$ & 1.000 & \\
Remittances & $0.3685(0.0000)$ & $0.3419(0.0000)$ & $0.4105(0.0000)$ & 1.000 \\
\hline
\end{tabular}

Significance level in parenthesis of $<0.05$ indicates strong correlation

Table 6 Principal component analysis results for Human Economic Welfare Enhancement (HEWE)

\begin{tabular}{llllll}
\hline Component & Eigenvalue & Difference & Proportion & Cumulative & \\
\hline Comp 1 & 2.982 & 2.189 & 0.7457 & 0.7457 & \\
Comp 2 & 0.793 & 0.649 & 0.1983 & 0.9440 & \\
Comp 3 & 0.143 & 0.0627 & 0.0358 & 0.9798 & \\
Comp 4 & 0.0806 & - & 0.0202 & 1.000 & \\
Principal components (eigenvectors) & & & & \\
Variable & Comp 1 & Comp 2 & Comp 3 & Comp 4 & Unexplained \\
Remittances & 0.3102 & 0.9476 & 0.0683 & 0.0342 & 0 \\
Consumption & 0.5467 & -0.1158 & -0.8220 & -0.1093 & 0 \\
Health & 0.5503 & -0.1911 & 0.4801 & -0.6558 & 0 \\
Education & 0.5496 & -0.2284 & 0.2984 & 0.7461 & 0 \\
Scoring coefficients & & & & & \\
Sum of squares (column-loading) $=1$ & & & Comp 4 & \\
Variable & Comp 1 & Comp 2 & Comp 3 & 0.0342 & \\
Remittances & 0.3102 & 0.9476 & 0.0683 & -0.1093 & \\
Consumption & 0.5467 & -0.1158 & -0.8220 & -0.6558 & \\
Health & 0.5503 & -0.1911 & 0.4801 & 0.7461 & \\
Education & 0.5496 & -0.2284 & 0.2984 & & \\
\hline
\end{tabular}

Table 7 Correlation tests for foreign capital inflows and financial development's proxies

(a) Correlation test for domestic credit and money supply

Domestic credit Money supply

Domestic credit $\quad 1.000$

$\begin{array}{lll}\text { Money supply } & 0.7613(0.0000) & 1.000\end{array}$

(b) correlation test for FDI and official credit

FDI

Official credit

FDI

1.0000

Official credit

$-0.1304(0.0192)$

1.0000

Significance level in parenthesis of $<0.05$ indicates strong correlation 


\section{Appendix 2}

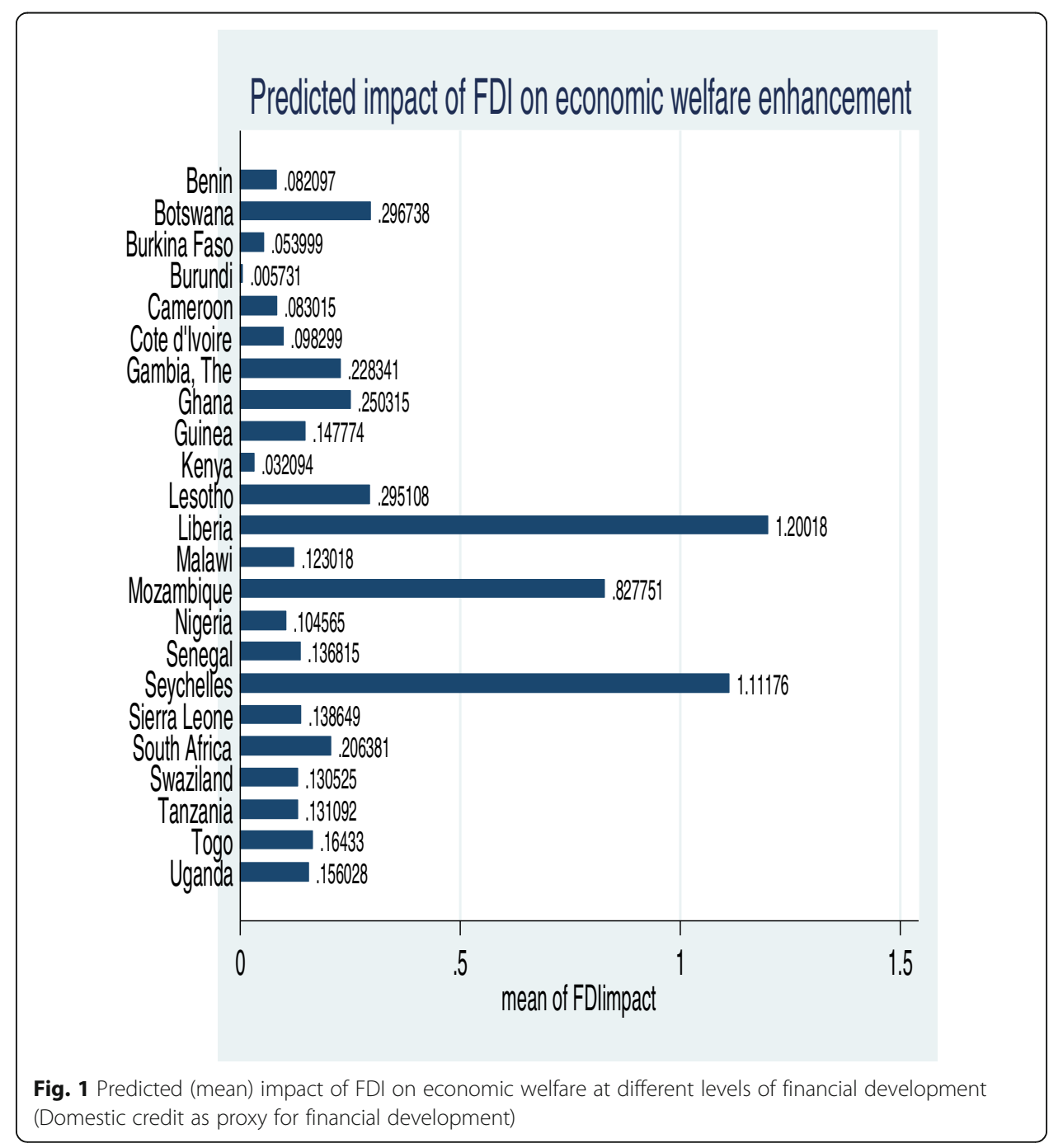




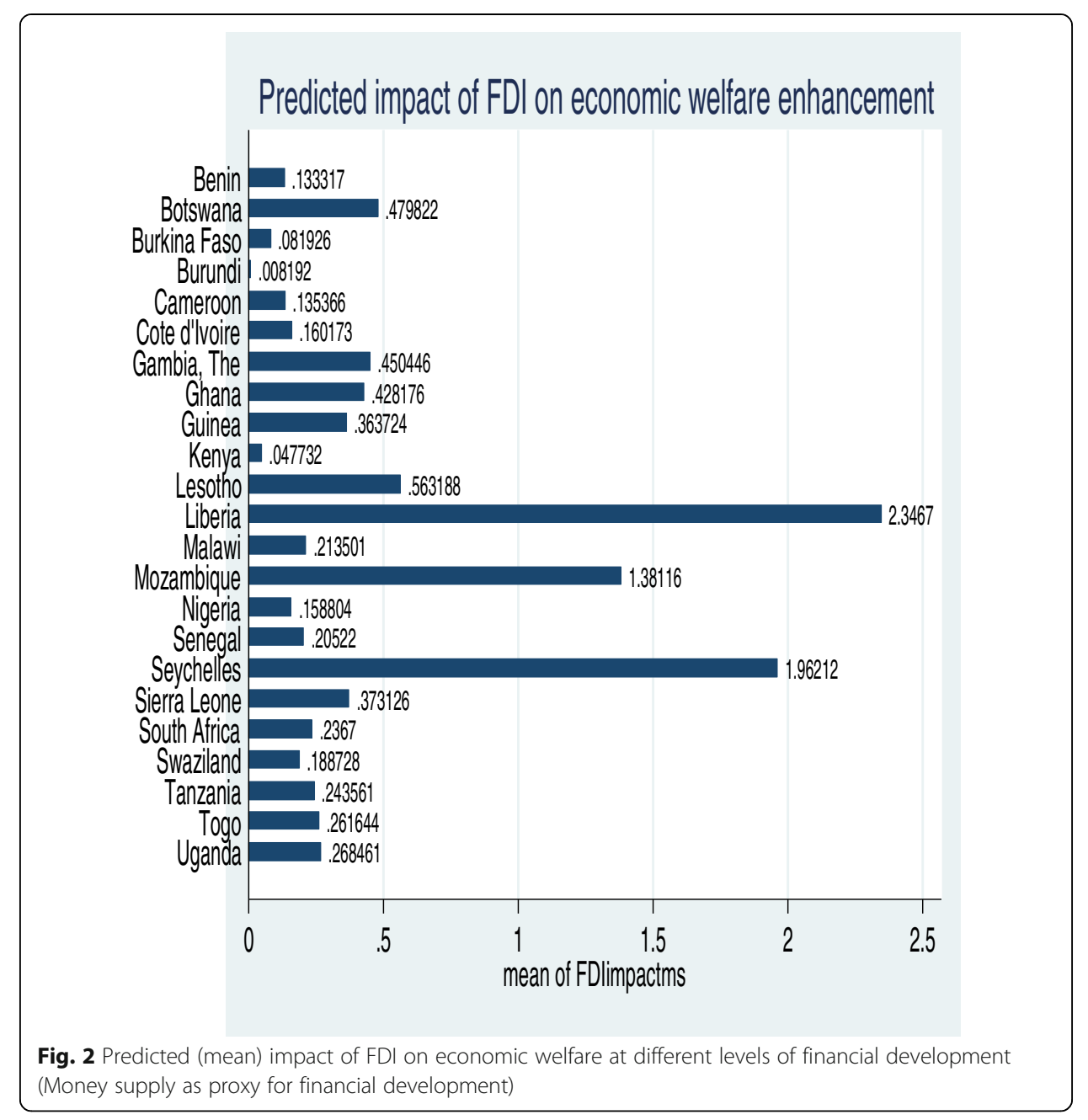




\section{Appendix 3}

Table 8 Interaction effect of FDI and DOMCR on HEWE, and its components except remittance

\begin{tabular}{lllll}
\hline Regressors & Education I & Health II & Consumption III & HEWE IV \\
\hline L1 of regressand & $0.989^{* * *}(0.053)$ & $0.948^{* * *}(0.038)$ & $1.050^{* * *}(0.044)$ & $1.028^{* * *}(0.041)$ \\
FDI & $-9.148^{* * *}(1.816)$ & $-9.031^{* * *}(2.189)$ & $-8.034^{* * *}(2.199)$ & $-13.321^{* * *}(3.461)$ \\
L1 FDI & $8.465^{* * *}(2.135)$ & $5.585^{* *}(2.059)$ & $9.512^{* * *}(1.944)$ & $14.585^{* * *}(3.282)$ \\
DOMCR & $-.0400(0.070)$ & $0.151^{*}(0.079)$ & $0.089^{*}(0.044)$ & $0.045(0.095)$ \\
L1 DOMCR & $0.026(0.056)$ & $-.0170^{* *}(0.070)$ & $-0.119^{* *}(.057)$ & $-0.129(0.098)$ \\
FDI*DOMCR & $2.915^{* * *}(0.662)$ & $3.688^{* * *}(0.800)$ & $2.752^{* * *}(0.751)$ & $4.953^{* * *}(1.373)$ \\
L1 FDI*DOMCR & $-2.910^{* * *}(0.747)$ & $-2.613^{* * *}(0.921)$ & $-3.396^{* * *}(0.775)$ & $-5.617^{* * *}(1.393)$ \\
Openness & $0.093(0.152)$ & $0.131(0.123)$ & $0.047(0.104)$ & $0.142(0.228)$ \\
Inflation & $-0.009^{* * *}(0.002)$ & $-0.013^{* * *}(0.002)$ & $-0.006^{* * *}(0.001)$ & $-0.015^{* * *}(0.003)$ \\
AR 1 & 0.002 & 0.001 & 0.002 & 0.003 \\
AR 2 & 0.241 & 0.111 & 0.071 & 0.539 \\
Hansen & 0.661 & 0.062 & 0.536 & 0.918 \\
\hline
\end{tabular}

Note: Values in parenthesis denote the robust standard errors of respective estimates. ${ }^{* * *} \mathrm{p}<0.01(1 \%),{ }^{* *} \mathrm{p}<0.05(5 \%)$ and ${ }^{*} p<0.095(10 \%)$ denote the level of significance. Time dummies from 2000 to 2013 not reported

Table 9 FDI and domestic credit as proxies for foreign capital inflows and financial development respectively

\begin{tabular}{llllll}
\hline Regressors & Remittances I & Education II & Health II & Consumption IV & HEWE V \\
\hline L1 of regressand & $0.943^{* * *}(0.117)$ & $0.989^{* * *}(0.053)$ & $0.948^{* *}(0.038)$ & $1.050^{* * *}(0.044)$ & $1.028^{* * *}(0.041)$ \\
FDI & $-5.438(5.565)$ & $-9.148^{* * *}(1.816)$ & $-9.031^{* *}(2.189)$ & $-8.034^{* * *}(2.199)$ & $-13.321^{* * *}(3.461)$ \\
L1 FDI & $2.874(2.400)$ & $8.465^{* * *}(2.135)$ & $5.585^{* *}(2.059)$ & $9.512^{* * *}(1.944)$ & $14.585^{* * *}(3.282)$ \\
DOMCR & $-0.238(0.161)$ & $-.0400(0.070)$ & $0.151^{*}(0.079)$ & $0.089^{*}(0.044)$ & $0.045(0.095)$ \\
L1 DOMCR & $0.1693(0.183)$ & $0.026(0.056)$ & $-.0170^{* *}(0.070)$ & $-0.119^{* *}(.057)$ & $-0.129(0.098)$ \\
FDI*DOMCR & $3.011(1.88)$ & $2.915^{* * *}(0.662)$ & $3.688^{* * *}(0.800)$ & $2.752^{* * *}(0.751)$ & $4.953^{* * *}(1.373)$ \\
L1 FDI*DOMCR & $-1.910^{* *}(0.948)$ & $-2.910^{* * *}(0.747)$ & $-2.613^{* * *}(0.921)$ & $-3.396^{* * *}(0.775)$ & $-5.617^{* * *}(1.393)$ \\
Openness & $0.209(0.580)$ & $0.093(0.152)$ & $0.131(0.123)$ & $0.047(0.104)$ & $0.142(0.228)$ \\
Inflation & $-.00003(0.010)$ & $-0.009^{* * *}(0.002)$ & $-0.013^{* * *}(0.002)$ & $-0.006^{* * *}(0.001)$ & $-0.015^{* * *}(0.003)$ \\
AR 1 & 0.018 & 0.002 & 0.001 & 0.002 & 0.003 \\
AR 2 & 0.834 & 0.241 & 0.111 & 0.071 & 0.539 \\
Hansen & 0.934 & 0.661 & 0.062 & 0.536 & 0.918 \\
\hline
\end{tabular}

Note: Values in parenthesis denote the robust standard errors of respective estimates. ${ }^{* * *} \mathrm{p}<0.01(1 \%),{ }^{* *} \mathrm{p}<0.05(5 \%)$ and ${ }^{*} \mathrm{p}<0.095(10 \%)$ denote the level of significance. Time dummies from 2000 to 2013 not reported 
Table 10 FDI and money supply as proxies for foreign capital inflows and financial development respectively

\begin{tabular}{llllll}
\hline Regressors & $\begin{array}{l}\text { Remittances } \\
\text { Model I }\end{array}$ & $\begin{array}{l}\text { Consumption } \\
\text { Model II }\end{array}$ & $\begin{array}{l}\text { Health } \\
\text { Model III }\end{array}$ & $\begin{array}{l}\text { Education } \\
\text { Model IV }\end{array}$ & HEWE \\
& Model V \\
\hline L1 of regressand & $0.957^{* * *}(0.104)$ & $1.020^{* * *}(0.056)$ & $0.928^{* * *}(0.064)$ & $1.045^{* * *}(0.055)$ & $1.027^{* * *}(0.044)$ \\
FDI & $-23.575(14.453)$ & $-9.931(6.099)$ & $-25.156^{* * *}(7.400)$ & $-11.373^{* *}(4.744)$ & $-23.762^{* * *}(7.967)$ \\
L1 FDI & $2.435(2.951)$ & $14.181^{* * *}(2.283)$ & $6.031^{* *}(2.725)$ & $14.306^{* * *}(1.963)$ & $21.112^{* * *}(3.378)$ \\
MS & $-0.304(0.267)$ & $-0.012(0.083)$ & $0.376^{* * *}(0.108)$ & $0.022(0.084)$ & $0.093(0.156)$ \\
L1 MS & $-0.142(0.220)$ & $-0.0261(0.084)$ & $-0.522^{* * *}(0.165)$ & $-0.0906(0.101)$ & $-0.362^{* *}(0.177)$ \\
FDI*MS & $7.417^{*}(4.137)$ & $2.549(1.643)$ & $7.344^{* * *}(1.991)$ & $2.892^{* *}(1.292)$ & $6.634^{* * *}(2.192)$ \\
L1 FDI*MS & $-1.501^{*}(0.775)$ & $-3.789^{* * *}(0.679)$ & $-2.134^{* * *}(0.733)$ & $-3.658^{* * *}(0.489)$ & $-5.952^{* * *}(0.982)$ \\
Openness & $0.433(0.569)$ & $0.087(0.131)$ & $0.154(0.168)$ & $-0.035(0.114)$ & $0.211(0.233)$ \\
Inflation & $-0.001(0.010)$ & $-0.006^{* * *}(0.001)$ & $-0.012^{* * *}(0.002)$ & $-.009^{* * *}(0.002)$ & $-0.016^{* * *}(0.003)$ \\
AR 1 & 0.019 & 0.003 & 0.000 & 0.003 & 0.008 \\
AR 2 & 0.733 & 0.107 & 0.025 & 0.238 & 0.356 \\
Hansen & 0.767 & 0.248 & 0.157 & 0.994 & 0.312 \\
\hline
\end{tabular}

Note: Values in parenthesis denote the robust standard errors of respective estimates. ${ }^{* *} p<0.01(1 \%),{ }^{* *} p<0.05(5 \%)$ and ${ }^{*} p<0.095(10 \%)$ denote the level of significance. Time dummies from 2000 to 2013 not reported

Table 11 Official credit and domestic credit as proxies for foreign capital inflows and financial development respectively

\begin{tabular}{llllll}
\hline Regressors & $\begin{array}{l}\text { Remittances } \\
\text { Model I }\end{array}$ & $\begin{array}{l}\text { Consumption } \\
\text { Model II }\end{array}$ & $\begin{array}{l}\text { Health } \\
\text { Model III }\end{array}$ & $\begin{array}{l}\text { Education } \\
\text { Model IV }\end{array}$ & $\begin{array}{l}\text { HEWE } \\
\text { Model V }\end{array}$ \\
\hline L1 of regressand & $1.053^{* * *}(0.192)$ & $0.754^{* * *}(0.191)$ & $0.776^{* * *}(0.184)$ & $0.812^{* * *}(0.153)$ & $0.918^{* * *}(0.174)$ \\
OFFCR & $0.046(0.130)$ & $0.0005(0.034)$ & $0.118(0.078)$ & $0.033(0.048)$ & $0.042(0.049)$ \\
L1 OFFCR & $0.017(0.090)$ & $0.016(0.034)$ & $-0.080(0.056)$ & $-0.019(0.032)$ & $-0.007(0.39)$ \\
DOMCR & $-0.259(0.272)$ & $0.212^{* * *}(0.069)$ & $0.385^{* *}(0.158)$ & $0.183^{*}(0.105)$ & $0.346^{*}(0.188)$ \\
L1 DOMCR & $0.151(0.277)$ & $-0.078(0.139)$ & $-0.227(0.139)$ & $0.003(0.130)$ & $-0.253^{* *}(0.123)$ \\
OFFCR*DOMCR & $-0.021(0.042)$ & $-0.004(0.010)$ & $-0.038(0.029)$ & $-0.009(0.013)$ & $-0.016(0.015)$ \\
L1 OFFCR*DOMCR & $0.0026(0.028)$ & $-0.001(0.011)$ & $0.026(0.023)$ & $0.008(0.012)$ & $0.007(0.014)$ \\
Openness & $-0.248(0.443)$ & $0.172(0.114)$ & $0.229(0.167)$ & $0.201(0.142)$ & $0.150(0.290)$ \\
Inflation & $0.004(0.007)$ & $0.001(0.002)$ & $0.001(0.005)$ & $0.002(0.003)$ & $0.002(0.005)$ \\
AR 1 & 0.012 & 0.042 & 0.002 & 0.090 & 0.062 \\
AR 2 & 0.812 & 0.130 & 0.644 & 0.309 & 0.295 \\
Hansen & 0.354 & 0.369 & 0.308 & 0.237 & 0.276 \\
\hline
\end{tabular}

Note: Values in parenthesis denote the robust standard errors of respective estimates. ${ }^{* * *} \mathrm{p}<0.01(1 \%),{ }^{* *} \mathrm{p}<0.05(5 \%)$ and ${ }^{*} p<0.095(10 \%)$ denote the level of significance. Time dummies from 2000 to 2013 not reported

\section{Appendix 4}

\section{Human economic welfare enhancement indicators}

An improved strand of theoretical supposition contend that government expenditure on education and health indicates investment in human capital. Moreover, household consumption expenditure and remittances are indicators of welfare enhancement. This section discusses the theoretical and empirical underpinnings of these contentions.

Jacobs and Slans (2010) contend that the instruments that pioneers of modern economics such as Adam Smith and David Ricardo use to measure their supposition are imprecise: attempts to place a value on all economic activities by means of pricing tend to ruin our intuition and human 
values. For example, can one conclude that spending millions of dollars to acquire military gadgets yield the same results as investing the same money in either public education or health? The make-up of the GDP gives an answer "yes" to this rhetorical question. Simon Kuznets, ${ }^{9}$ its creator, cautioned the U.S. congress as far back as 1934 about its shortcomings. He said "The Welfare of the nation can scarcely be inferred from national income as defined above". ${ }^{10}$ After thirty years, he proposed that we distinguish between quality and quantity of growth; cost and return; and short and long run. ${ }^{11} \mathrm{He}$ argues that natural disaster and crimes and the expenditure to redress them enter GDP computation as government expenditure; however, they are not investments in human capital. Notwithstanding, expenditures on education and training that are investments in human capital also enter GDP computation as government expenditure.

In view of the above criticism, this paper chooses variables, which directly serve as proxy measures of investment in human economic welfare: current government expenditure on education and health; household consumption expenditure; personal remittances. These variables are considered as good proxies on grounds that their effects are not always instantaneous but their returns occur suddenly overtime to reduce income inequality of the population.

Investment in education is a very important component when it comes to human economic welfare enhancement and well-being. Literature well documents the effect of education on income. Glaeser (2009) in a cross-country study suggests that 30\% rise in per capita income is attributable to one more year of education attained. Moreover, Card (1999:1801-1859) confirms the positive correlation between higher levels of education and higher levels of employment and income. He suggests that additional year of schooling increases ones earnings from 6 to $14 \%$ in all parts of the world. Nevertheless, other studies show weak association between education and GDP per capita in both low and high per capita countries when the education composite index of the UNDP is used (see UNDP 2009). This study confines itself to the aspect of education that directly affect delivery of knowledge to the society rather than educational development. This is because this knowledge assist the society to get the necessary skills and training that they require for future higher levels of employment and corresponding income. For example, government expenditure on teachers' wages and salaries; teaching materials; allowances for teachers' accommodation have direct effect on knowledge impact.

Investment in healthcare is another important element of human economic welfare enhancement. For example, expenditure on healthcare intended to extend one's life span for a day, week, months or years cannot me quantified as equal as the cost incurred. Therefore, expenditure on healthcare is considered as one of welfare investment variables (see Jacobs and Slans 2010). Moreover, many empirical studies have established a relationship between healthcare expenditure and GDP per capita. In a cross sectional study, Kleiman (1974) and Newhouse (1977) examine the correlation between real healthcare consumption expenditure per capita (HE) and real per capita income (GDP). These two studies suggest a strong relationship between HE and GDP. They also conclude that the changes in HE are mostly as a result of changes in GDP. Nevertheless, the inclusion of healthcare expenditure in the GDP's computation is likely to make their results spurious. Many other studies have achieved similar results by expressing HE as a function of GDP (see Hansen and King 1996; Newhouse 1977; Parkin et al. 1987; Milne and Molana 1991; Gerdtham and Jönsson 1991; Hitiris and Posnett 1992). Many empirical works conclude that national income largely determines the size of healthcare expenditure. Fuchs (1996) testifies that $85 \%$ of advanced researchers in health economics have come to that conclusion. In a recent study, Sghari and Hammami (2013) undertake a panel study on 30 developed countries from 1975 to 2011 to ascertain if increase in healthcare expenditure has positive effect on GDP growth and vice versa. 
The study suggests that increase in health care expenditure has the possibility of increasing GDP, given that the health of the population determines the output of the country. This study has similar issues like that of the time series: health expenditure already captured in the GDP, which makes the result to be highly spurious. Nevertheless, the fact that investment in health has positive effect on the welfare of the economic agents cannot be overemphasized.

In as much as one should not be strict about choosing consumption expenditure over income as a monetary measure of welfare, many researchers prefer to use consumption expenditure for a peculiar reason. The World Bank (2016) suggests that so long as consumption data captures all aspect of household consumption, researchers prefer it to income. This is so because actual consumption depicts availability and accessibility of goods and services to satisfy basic needs; income does not automatically give access to or make available commodities one requires to meet basic needs. This makes consumption expenditure more linked to well-being than actual income. Moreover, accuracy highly exists in the measurement of consumption than income. This is so because of the irregularity in the pattern of income flows of economies where the informal sector constitutes a greater percentage of the real sector; such as some poor agrarian and urban economies. In the case of those in agriculture, many farmers find it difficult to ascertain their actual earnings by accurately determining the monetary value of their inputs. Furthermore, the part of the produce that they use for domestic consumption are mostly unquantified in monetary terms as part of their income. Thus, while the estimation of consumption may have its own challenges, it is likely to be a better measure of welfare than income. In addition to the above, the World Bank (2016) explains how consumption expenditure brings out the ability of economic agents to access credit markets to level their consumption patterns in times of low or zero income. Therefore, household consumption expenditures do well in measuring the human economic welfare enhancement that their income.

Remittances are financial flows into households that are not conditional on quid pro quo (see Addison 2005). Their countercyclical nature appears to smoothen consumption patterns of households in times of low and zero income. Russell et al. (1990) in their IMF Country Analysis Report reveal that many communities in developing countries depend on remittances for their livelihood. Their conclusion suggest that these remittances capacitate even the poor who has diffculty in accessing credit facility to invest in education, healthcare and other business after they have met their basic needs of sustenance. Koc and Onan (2001) establish a positive effect of remittances on standard of living in Turkey using a Turkish International Migration Survey (TIMS-96) dataset. Their study reveals direct and indirect effect of remittances on the incomes of the poor, which consequently improves economic welfare. Moreover, remittances do well in enhancing savings and investment in poor communities (see Taylor 1996). Some studies show that they help the rural poor to pay for the cost of farming inputs such as irrigation and enhances their livelihood in successful harvest (see for example Findley and Sow 1998; Ahmed 2000; Kannan and Hari 2002). Thus, they have positive consequences on recipients' savings, investment and production. Nevertheless, remittances potentially cause appreciation of real exchange rate and higher inflation if not prudently managed (see Amuedo-Dorantes and Pozo 2002). These have the effects of reducing the real income of economic agents and hence their well-being. However, well-managed remittances can reduce poverty. In a related study of 74 low and middle-income developing countries, Adams and Page (2003) suggest $1.9 \%$ fall in poverty for every $10 \%$ rise of international migrants of the population. Although, other studies contend that the rich is likely to afford to send relatives abroad and hence such remittances tend to widen income inequality (see Adams 1991), many of the studies support the fact that remittances reduce income inequality (see also, Gustafsson and Makonnen 1994; Chimhowu et al. 2004). 


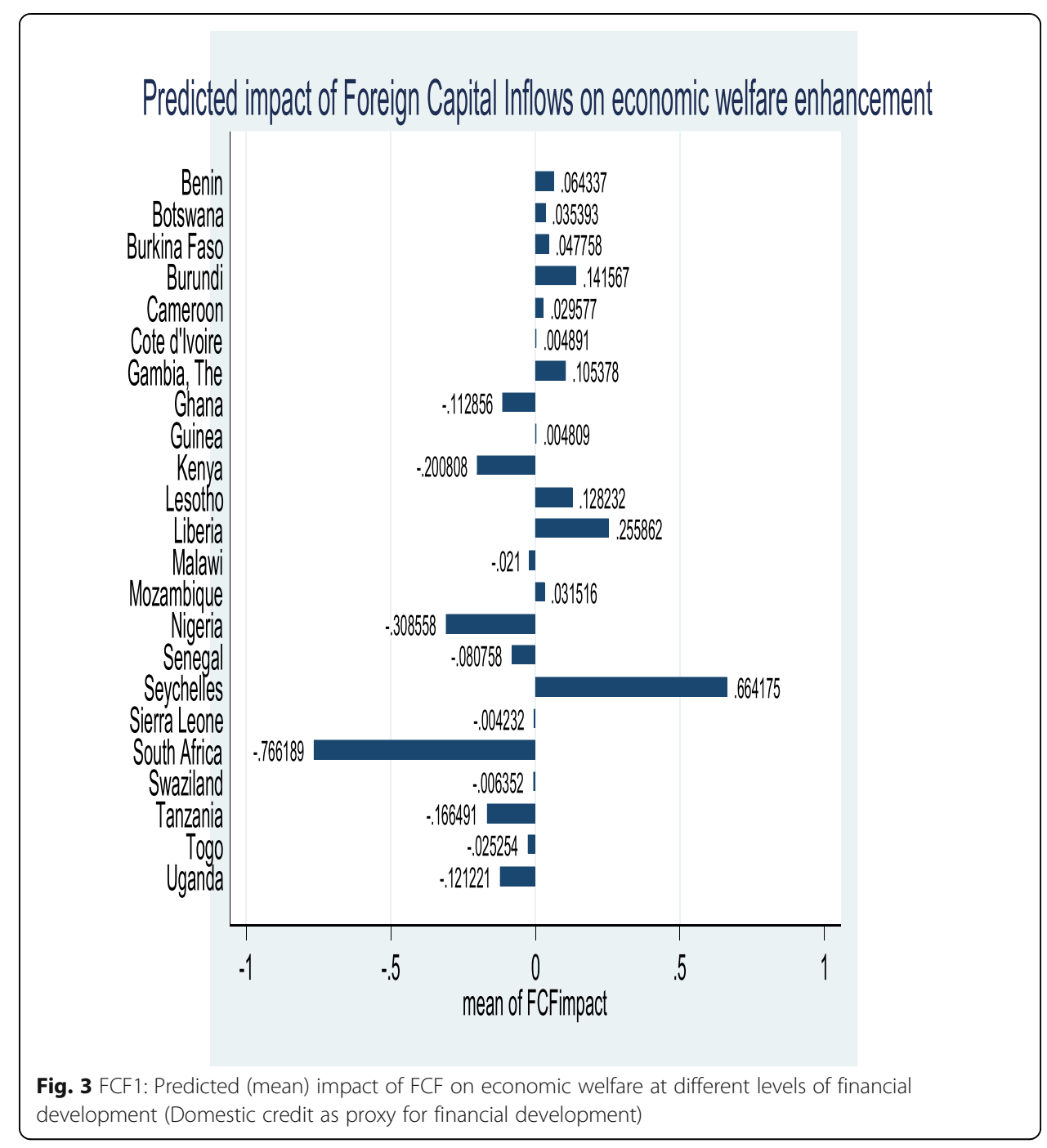




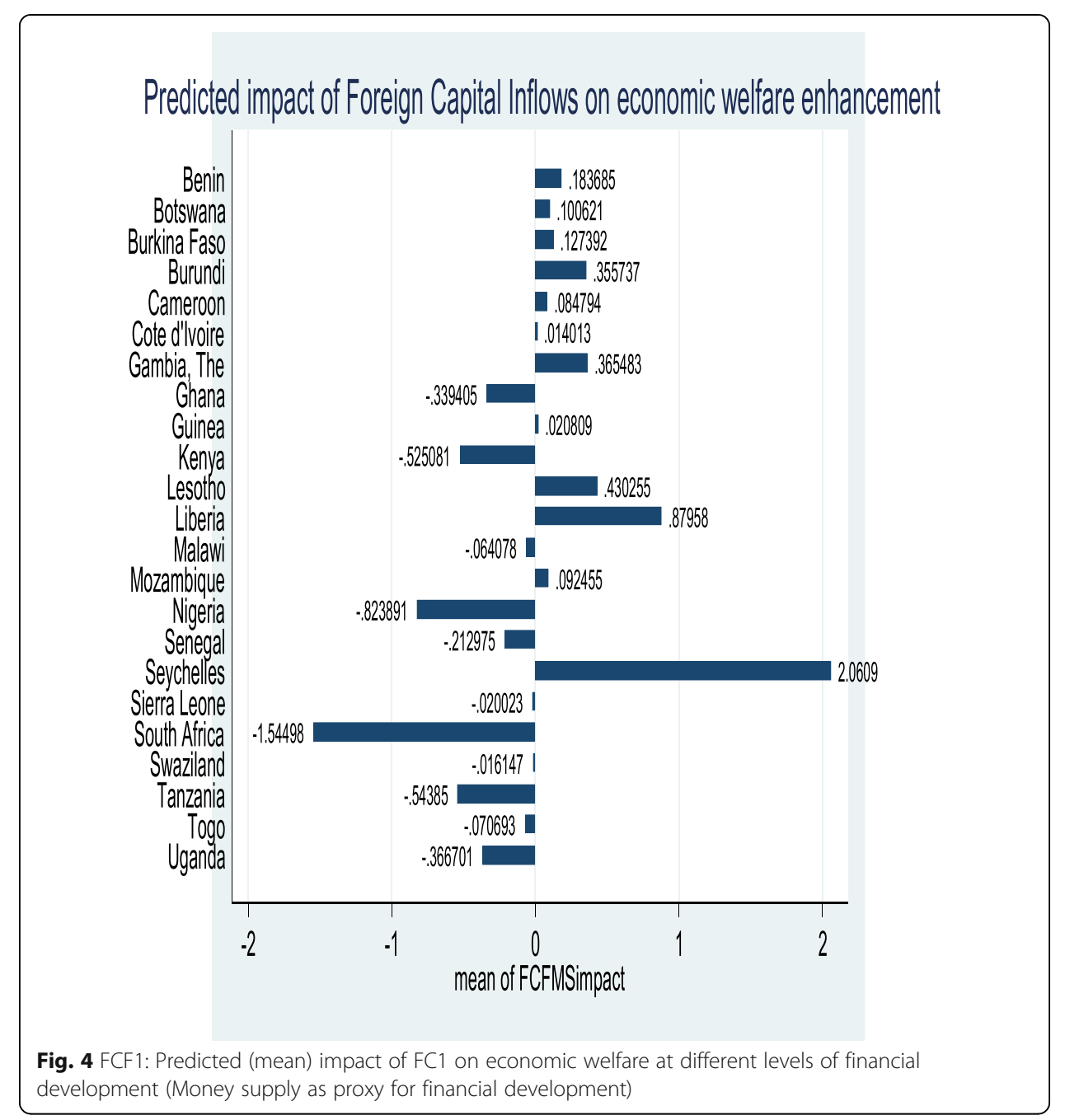




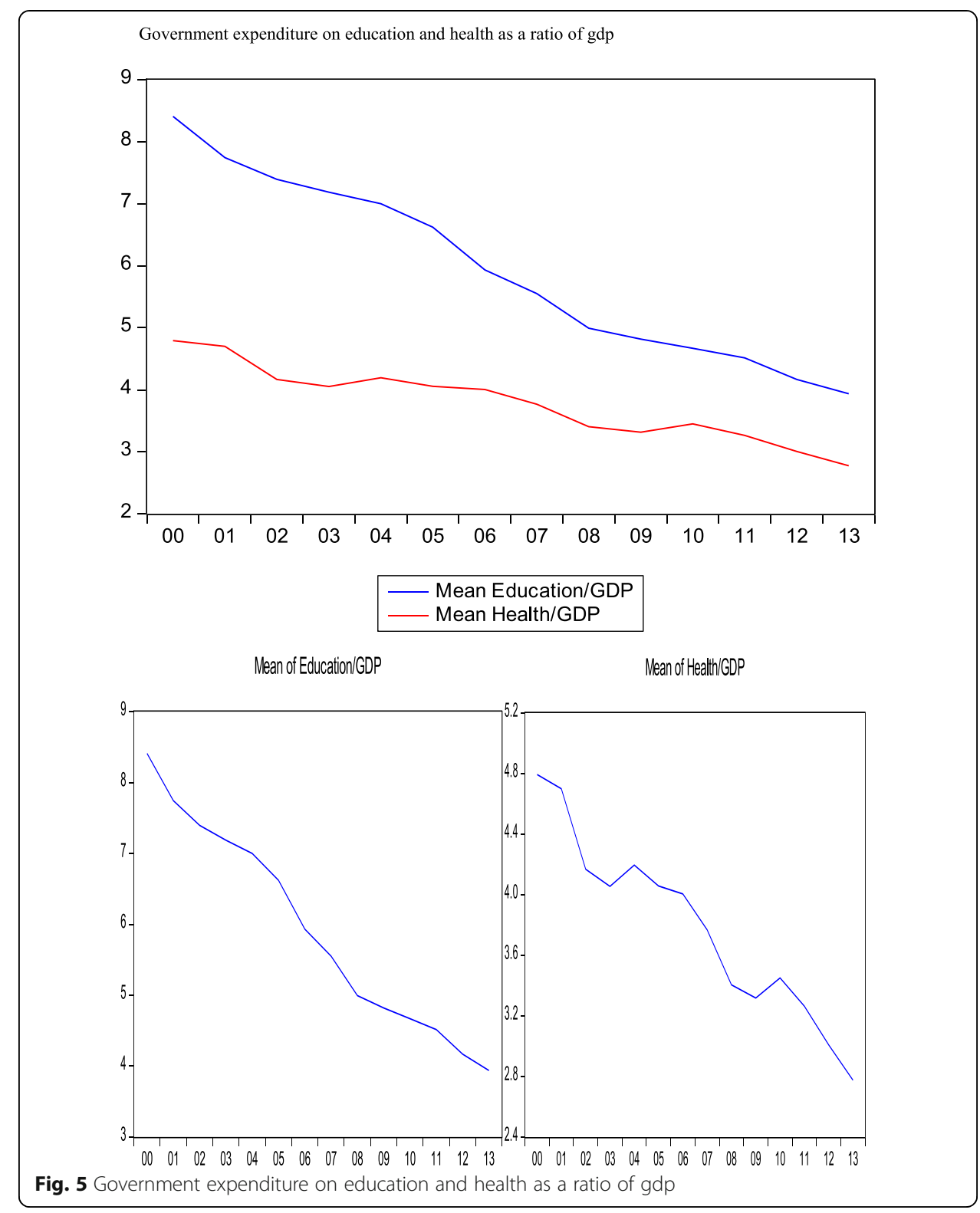




\section{Appendix 5}

Table 12 Dynamic panel data estimation, one-step system GMM: interaction effect of Portfolio inflow and financial development on HEWE

\begin{tabular}{lll}
\hline Regressors & Model I & Model II \\
\hline HEWE & $1.066783^{* * *}(.0850911)$ & $1.061039^{* * *}(.0575306)$ \\
L1 HEWE & $-1.587012(1.963031)$ & $-2.884131(3.382766)$ \\
Portfolio & $1.492666(1.869803)$ & $2.756517(3.22638)$ \\
L1 Portfolio & $.5636969(.5855804)$ & - \\
DOMCR & $-.6569331(.6164778)$ & - \\
L1 DOMCR & - & $1.455801(1.234993)$ \\
MS & - & $-1.49361(1.131402)$ \\
L1 MS & $.3211547(.3985153)$ & - \\
Portfolio*DOMCR & $-.3023585(.3781958)$ & - \\
L1 Portfolio*DOMCR & - & $.6581486(.7716539)$ \\
Portfolio*MS & - & $-.6250998(.7318689)$ \\
L1 Portfolio*MS & $.1083707(.1823728)$ & $-.0837796(.1763114)$ \\
Openness & $-.0162765^{* * *}(.0029864)$ & $-.0132394^{* * *}(.0028253)$ \\
Inflation & 0.123 & 0.145 \\
AR 1 & 0.154 & 0.277 \\
AR 2 & 0.501 & 0.272 \\
Hansen & &
\end{tabular}

Note: Values in parenthesis denote the robust standard errors of respective estimates. ${ }^{* * *} p<0.01(1 \%),{ }^{* *} p<0.05(5 \%)$ and ${ }^{*} p<0.10$ (10\%) denote the level of significance. Time dummies from 2000 to 2013 not reported. Number of observation: $N=23 ; T=14$.

Portfolio inflow is used as indicator for FCF; DOMCR and MS are used as indicators for FD in both eqs. (1) 
Table 13 Dynamic panel data estimation, one-step system GMM: interaction effect of Private Creditors and financial development on HEWE

\begin{tabular}{lll}
\hline Regressors & Model I & Model II \\
\hline HEWE & $1.067527^{* * *}(.0736107)$ & $1.034372^{* * *}(.0310108)$ \\
L1 HEWE & $38.16728(224.8028)$ & $15.04816(47.04743)$ \\
Private creditors & $36.44954(84.47849)$ & $9.583578(21.01398)$ \\
L1 Private creditors & $.1622903(.235105)$ & - \\
DOMCR & $-.2334195^{*}(.1201478)$ & - \\
L1 DOMCR & - & $.3250248^{*}(.1740122)$ \\
MS & - & $-.4128301^{* * *}(.1169096)$ \\
L1 MS & $-13.71776(68.70689)$ & - \\
Private creditors*DOMCR & $-12.23399(25.2259)$ & - \\
L1 Private creditors*DOMCR & - & $-4.005739(10.9315)$ \\
Private creditors *MS & - & $-1.933295(4.696352)$ \\
L1 Private creditors *MS & $.0529606(.2093308)$ & $-.0461291(.2456225)$ \\
Openness & $-.0152063^{* * *}(.0046217)$ & $-.0136163^{* * *}(.004243)$ \\
Inflation & 0.151 & 0.173 \\
AR 1 & 0.279 & 0.327 \\
AR 2 & 0.274 & 0.164 \\
Hansen & & \\
\hline
\end{tabular}

Note: Values in parenthesis denote the robust standard errors of respective estimates. ${ }^{* * *} p<0.01(1 \%),{ }^{* *} p<0.05(5 \%)$ and ${ }^{*} p<0.10(10 \%)$ denote the level of significance. Time dummies from 2000 to 2013 not reported. Number of observation: $N=23 ; \mathrm{T}=14$. Private credit is used as indicator for FCF; DOMCR and MS are used as indicators for FD in both eqs. (1)

\section{Appendix 6}

Table 14 Correlation test for Foreign Capital Inflows components

\begin{tabular}{llllc}
\hline & Official credit & FDI & Portfolio & Private credit \\
\hline Official credit & 1.000 & & & \\
FDI & $-0.1304(0.0192)$ & 1.000 & & \\
Portfolio & $0.2803(0.0000)$ & $0.2061(0.0002)$ & 1.000 & 1.000 \\
Private credit & $0.0114(0.8386)$ & $0.1732(0.0018)$ & $0.1071(0.0549)$ & \\
\hline
\end{tabular}

Significance level in parenthesis of $<0.05$ indicates strong correlation

Table 15 Principal component analysis results for Foreign Capital Inflows (FCF)

\begin{tabular}{llllll}
\hline Component & Eigenvalue & Difference & Proportion & Cumulative & \\
\hline FCF 1 & 1.36191 & .173449 & 0.3405 & 0.3405 & \\
FCF 2 & 1.18846 & .319729 & 0.2971 & 0.6376 & \\
FCF 3 & .868735 & .287846 & 0.2172 & 0.8548 & \\
FCF 4 & .580889 & - & 0.1452 & 1.0000 & \\
Principal components (eigenvectors) & & & & \\
Variable & FCF 1 & FCF 2 & FCF 3 & FCF 4 & Unexplained \\
Private creditors & 0.4326 & -0.3554 & 0.8257 & 0.0698 & 0 \\
Portfolio & 0.6796 & 0.2231 & -0.3128 & 0.6249 & 0 \\
Official credit & 0.3746 & 0.7056 & 0.1566 & 0.5808 & 0 \\
FDI & 0.4591 & -0.5710 & -0.4426 & 0.5170 & 0 \\
\hline
\end{tabular}


Table 16 Dynamic panel data estimation, one-step system GMM: interaction effect of Foreign Capital Inflows and financial development on Economic Welfare Enhancement (HEWE)

\begin{tabular}{lll}
\hline Regressors & Model I & Model II \\
\hline HEWE & & \\
L1 HEWE & $1.05026^{* *}(.067888)$ & $1.055274^{* * *}(.0521979)$ \\
Foreign capital & $-.3456396^{* *}(.1388701)$ & $-.7379674^{* *}(.3180895)$ \\
L1 Foreign capital & $.3170124(.1891328)$ & $.8461276^{* *}(.3086171)$ \\
DOMCR & $.1258294(.0969015)$ & - \\
L1 DOMCR & $-.2507615^{*}(.1363124)$ & - \\
MS & - & $.2563974^{* *}(.1091607)$ \\
L1 MS & - & $-.5087709^{* * *}(.1708052)$ \\
Foreign capital*DOMCR & $.0716798^{* *}(.0304995)$ & - \\
L1 Foreign capital*DOMCR & $-.0745964(.046233)$ & - \\
Foreign capital*MS & - & $.1687956^{* *}(.0751464)$ \\
L1 Foreign capital*MS & - & $-.1969856^{* *}(.07438)$ \\
Openness & $.169548(.2061599)$ & $.1370745(.2062196)$ \\
Inflation & $-.016217^{* * *}(.0031808)$ & $-.0152768^{* * *}(.0031403)$ \\
AR 1 & 0.048 & 0.012 \\
AR 2 & 0.586 & 0.300 \\
Hansen & 0.426 & 0.705 \\
\hline
\end{tabular}

Note: Values in parenthesis denote the robust standard errors of respective estimates. ${ }^{* * *} \mathrm{p}<0.01(1 \%),{ }^{* *} \mathrm{p}<0.05(5 \%)$ and ${ }^{*} p<0.10(10 \%)$ denote the level of significance. Time dummies from 2000 to 2013 not reported. Number of observation: $\mathrm{N}=23 ; \mathrm{T}=14$. Foreign capital inflow having portfolio, $\mathrm{FDI}$, private credit and official credit registering eigenvectors of $0.6796,0.4591,0.4326$, and 0.3746 respectively; DOMCR and MS are used as indicators for FD in both eqs. (1)

Table 17 Foreign capital inflows $(\mathrm{fc} 1=\mathrm{pc} 1=\mathrm{comp} 1)$, of which portfolio registers the highest eigenvector of 0.6796 , interacts with financial development

\begin{tabular}{|c|c|c|c|c|}
\hline & \multicolumn{2}{|c|}{ Domestic credit } & \multicolumn{2}{|l|}{ Money supply } \\
\hline & level & $\overline{\mathrm{lag}}$ & level & lag \\
\hline Partial direct effect of FCF1 & -.3456396 & - & .7379674 & .8461276 \\
\hline $\begin{array}{l}\text { Interactive effect of FCF1 and financial } \\
\text { development }\end{array}$ & .0716798 & - & .1687956 & .1969856 \\
\hline $\begin{array}{l}\text { Partial indirect effect of FCF1 conditional on } \\
\text { the mean of financial development }\end{array}$ & $\begin{array}{l}.0716798 \times \\
2.725= \\
0.195327455\end{array}$ & - & $\begin{array}{l}.1687956 \times \\
3.371= \\
0.5690099676\end{array}$ & $\begin{array}{l}.1969856 \times \\
3.371= \\
0.6640384576\end{array}$ \\
\hline
\end{tabular}

$\partial H E W E_{i, t} / \partial F C F 1_{i, t}=\beta_{c 1}+\left(\rho_{c 1} \times\right.$ mean of $F D_{i, t ;}$ Mean of Domestic Credit $=2.725 ;$ mean of Money Supply $=3.371$. Values are significant at $5 \%$ level 


\section{Additional file}

Additional file 1: Declarations. (XLS $274 \mathrm{~kb})$

\section{Abbreviations}

2SLS: Two-stage least square; AGOA: African growth and opportunity act; AR: Autoregressive; DOMCR: Domestic credit to the private sector; EBA: Everything but arms; FCF: Foreign capital inflows; FCF1: First Principal Component of Foreign Capital Inflows; FCF2: Second Principal Component of Foreign Capital Inflows; FD: Financial development; FDI: Foreign direct investment; FE: Fixed effect; GDP: Gross domestic product; GMM: Generalized method of moments; HEWE: Human economic welfare enhancement; HEWE1: First Principal Component of Human Economic Welfare Enhancement; Ingoveeppc: Natural logarithm of government recurrent expenditure on education per capita; Ingovhepc: Natural logarithm of government recurrent expenditure on health per capita; Inhcepc: Natural logarithm of household consumption expenditure per capita; Inrempc: Natural logarithm of remittances received per capita; IV: Instrumental variables; MNE: Multi-national enterprises; MS: Money supply; NHIS: National health insurance scheme; OFFCR: Official credit inflows; OLS: Ordinary least squares; PCA: Principal component analysis; PIH: Permanent income hypothesis; SHS: Senior High School; SSA: sub-Saharan Africa; WDI: World development indicator

\section{Acknowledgements}

I thank Dr. George Adu (my second PhD supervisor) who supplied me with some relevant materials, offered constructive critique, and assisted me to address some of the first issues that were raised in the review process.

\section{Funding}

The Government of Ghana subsidizes the cost of Graduate Students' research at the Kwame Nkrumah University of Science and Technology (KNUST), Kumasi, Ghana. A total of $\$ 400$ was received for a period of four years, nevertheless, competing interest does not apply to the paper.

\section{Availability of data and materials}

The paper studies twenty-three Sub-Saharan African countries ( $N=23)$ for a time dimension of 2000-2013 (T=14).The chosen time dimension and the number of countries are guided by the availability of data. The study draws most of its data from WDI (2015). Data is available as an Additional file 1 in excel.

\section{Authors' contributions}

I, KA, personally undertook this research paper and addressed all the issues raised by the professional reviewers of the Journal. I (author) read and approved the final manuscript.

\section{Ethics approval and consent to participate}

Not applicable.

\section{Consent for publication}

I, Kwame Acheampong (author), personally approve that the paper should be published in your journal.

\section{Competing interests}

Not applicable.

\section{Publisher's Note}

Springer Nature remains neutral with regard to jurisdictional claims in published maps and institutional affiliations.

\section{Received: 12 April 2017 Accepted: 23 April 2019}

Published online: 21 June 2019

\section{References}

Adams R.H (1991), "The effects of international remittances on poverty, inequality, and development on rural Egypt," International Food Policy Research Institute Research Report 86

Adams RH, Page J (2003) Impact of international migration and remittances on poverty. A paper presented at the DFID/WB conference on migrant remittances, London October 9-10 2003

Addison EKY (2005) In: Manuh T (ed) The macroeconomic impact of remittances, in at home in the world, international migration and development, a contemporary Ghana and West Africa. Sub-Saharan Publishers, pp 118-138

Adeniyi O, Ajide B, Salisu A (2015) Foreign capital flows, financial development and growth in sub-Saharan Africa. J Econ Dev 40:3 09/15

Ahmed I (2000) Remittances and their economic impact in post-war Somaliland. Disasters 24(4):380-389

Aitken BJ, Harrison AE (1999) Do domestic firms benefit from direct foreign investment? Evidence from Venezuela. Am Econ Rev:605-618

Amuedo-Dorantes, C. and Pozo, S. (2002) "Workers' remittances and the real exchange rate: the paradox of gifts."http:// homepages.wmich.edu/ pozo/remit.real.feb6.pdf

Andrianova, S, B Baltagi, PO Demetriades, and D Fielding (2011), "Why Do African Banks Lend So Little?", University of Leicester Working Paper 11/19

Ang JB, Madsen JB (2013) International R\&D spillovers and productivity trends in the Asian miracle economies. Econ Inq 51(2):1523-1541 
Asongu SA (2013) Investment and inequality in Africa: which financial channels are good for the poor? Afr Finance J 15(2): 43-65

Banerjee AV, Newman AF (1993) Occupational choice and the process of development. J Polit Econ 101(2):274-298 Bitzer J, Kerekes M (2008) Does foreign direct investment transfer technology across borders? New evidence. Econ Lett 100: $355-358$

Card D (1999) "The causal effects of education on earnings", chapter 30. In: Handbook of Labour Economics, Volume 3. Ashenfelter, pp 1801-1859. Accessed 1 Sep 2010 http://emlab.berkeley.edu/users/card/papers/causal_educ_earnings.pdf. http://emlab.berkeley.edu/users/card/papers/causal_educ_earnings.pdf

Chea A (2011) Global private capital flows and development finance in sub-Saharan Africa: exemplary performers, lessons for others and strategies for global competitiveness in the twenty-first century. Int J Sustain Dev 4(5):18

Chimhowu, A. Piesse J., and Pinder C. (2004) "The impact of remittances" Enterprise Development Impact Assessment Information Service EDIAIS, Issue 29, April 2004

Clarke G, Xu LC, Zou H-F (2006) Finance and income inequality: what do the data tell us? South Econ J 76(3):578-596

Cleeve E (2008) How effective are fiscal incentives to attract FDI to sub-Saharan Africa. J Dev Areas 42(1):135-153 September 2008

Clifford, C., Halstead, T. and Jonathan R. (2010), "If the GDP is up, why is America down?" Atlantic Monthly, October 2, 2010. http://www.theatlantic.com/past/politics/ecbig/gdp.htm

Damijan JP, Knell M, Majcen B, Rojec M (2003) The role of FDI, R\&D accumulation and trade in transferring technology to transition countries: evidence from firm panel data for eight transition countries. Econ Syst 27(2): 189-204

Deaton A (2003) Health, inequality, and economic development. J Econ Lit 41(1):113-158

Deaton, A. (2004). Health in an Age of Globalization (no. w10669). National Bureau of Economic Research

Delechat C, Ramirez G, Wagh S, Wakeman-Linn J (2009) Sub-Saharan Africa's integration in the global financial markets, Working paper 09/114. IMF, Washington, DC

Djankov S, Hoekman B (2000) Foreign investment and productivity growth in Czech enterprises. World Bank Econ Rev 14(1): 49-64

Enowbi Batuo, M., Guidi, F., \& Mlambo, K. (2010). Financial development and income inequality: evidence from African countries

Eskeland GS, Harrison AE (2003) Moving to greener pastures? Multinationals and the pollution haven hypothesis. J Dev Econ 70(1):1-23

Figlio DN, Blonigen BA (2000) The effects of foreign direct investment on local communities. J Urban Econ 48(2):338-363

Findley S, Sow S (1998) In: Appleyard R (ed) From season to season: agriculture, poverty, and migration in the Senegal River valley, Mali. Emigration dynamics in DevelopingCountries: sub-Saharan Africa. Ashgate Publishing Ltd. 1, London, pp 69-144

Friedman M (1957) A theory of the consumption functionll. Princeton University Press, Princeton

Fuchs VR (1996) Economics, values, and health care reform. Am Econ Rev 86(1):1-24

Galor O, Zeira J (1993) Income distribution and macroeconomics. Rev Econ Stud 60(1):35-52

Gemmell N, Kneller R, Sanz I (2008) Foreign investment, international trade and the size and structure of public expenditures. Eur J Polit Econ 24(1):151-171

Gerdtham U, Jönsson B (1991) Price and quantity in international comparisons of health care expenditure. Appl Econ 23: $1519-1528$

Glaeser EG (2009) Education last century and economic growth today. The New York Times, Accessed 1 Sep 12010 http:// economix.blogs.nytimes.com/2009/10/20/education-last-century-and-economic-growth-today

Greenwood J, Jovanovic B (1990) Financial development, growth, and the distribution of income. J Polit Econ 98(5):10761107

Gries T, Meierrieks D (2010) Institutional quality and financial development in sub-saharan africa. University of Paderborn, Department of Economics available at: www.csae.ox.ac.uk/conference/2010-EdiA/papers/174-Gries.pdf

Gruber J, Kamin S (2009) Do differences in financial development explain the global pattern of current account imbalances? Rev Int Econ 17(4):667-688

Gustafsson B, Makonnen N (1994) The importance of remittances for the level and distribution of economic well-being in Lesotho. J Int Dev 6(4):373-397

Hansen P, King A (1996) The determinants of healthcare expenditure: a cointegration approach. J Health Econ 15:127-137

Hausmann R, Fernández-Arias E (2000) Foreign direct investment: good cholesterol?, working paper, inter American development Bank. Research Department, p 417

Herzer D, Nunnenkamp P (2012) FDI and health in developed economies: A panel cointegration analysis, Kiel Working Paper, No. 1756. Kiel Institute for the World Economy (IfW), Kiel

Hitiris T, Posnett J (1992) The determinants and effects of health expenditure in developed countries. J Health Econ 11(2):173-181

Jacobs, G., and Slans, I. (2010) New economic theory: indicators of economic Progress: the power of measurement and human welfare. Cadmus, promoting leadership in thought that leads to action. Voulume 1, no. 1, October, 2010. http:// cadmusjournal.org/

Kai H, Hamori S (2009) Globalization, financial depth, and inequality in sub-Saharan Africa. Econ Bull 29(3):2025-2037

Kannan KP, Hari KS (2002) Kerala's gulf connection: emigration, remittances and their macroeconomic impact 1972-2000. Centre for Development Studies Working Paper 328. http://cds.edu/download_files/328.pdf

Kappel, Vivien, The Effects of Financial Development on Income Inequality and Poverty. (2010). CER-ETH - Center of Economic Research at ETH Zurich, Working Paper No. 10/127. Available at SSRN: https://ssrn.com/abstract=1585148 or https://doi. org/10.2139/ssrn.1585148

Kim DH, Lin SC (2011) Nonlinearity in the financial development-income inequality nexus. J Comp Econ 39(3):310-325

Kleiman E (1974) The determinants of national outlay on health. In: Perlman (ed) The economics of health and medical care. Wiley, New York

Koc I. and Onan I., (2001), "The impact of remittances of international migrants on the standard of living of the left-behind families in Turkey" 
Kuznets S (1955) Economic growth and income inequality. Am Econ Rev XLV (1):1-28

Law SH, Tan HB, Azman-Saini WNW (2014) Financial development and income inequality at different levels of institutional quality. Emerg Mark Financ Trade 50(sup1):21-33

Levine R, Zervos S (1998) Stock markets, banks, and economic growth. Am Econ Rev 88:537-558

Milne R, Molana H (1991) On the effect of income and relative price on demand for health care: EC evidence. Appl Econ 23(7):1221-1226

Mlachila MM, Takebe MM (2011) FDI from BRICS to LICS: Emerging growth driver? (no. 11-178). International Monetary Fund Nagel K, Herzer D, Nunnenkamp P (2015) How does FDI affect health? Int Econ J 29(4):655-679. https://doi.org/10.1080/ 10168737.2015.1103772

Newhouse JP (1977) Medical-care expenditure: a cross-national survey. J Hum Resour 12(1):115-125

Nissanke M, Aryeetey E (2008) Institutional analysis of financial market fragmentation in sub-Saharan Africa: a risk-cost configuration approach. In: Domestic resource mobilization and financial development. Palgrave Macmillan UK, pp $112-145$

Nordhaus, W.D. and Tobin, J (1973) "Is growth obsolete?" The measurement of economic and social performance, studies in income and wealth, Vol.38 NBER, 1973. Cowles Foundation discussion paper 319, Cowles Foundation, Yale University. Accessed 10 Aug 2010, http://cowls.econ.yale.edu/P/cp/p0398ab.pdf

Ocaya B (2012) The Current Global Credit Crunch: A Review of its Causes, Effects and Responses. Online J Soc Sci Res, ISSN 2277-0844 1(6):166-177

Parkin D, McGuire A, Yule B (1987) Aggregate health care expenditures and national income: is health care a luxury good? J Health Econ 6(2):109-127

Prasad E (2007) Welfare implications of global financial flows, the. Cato J 27:185

Rodrik D (1998) Why do more open economies have bigger governments. J Polit Econ 106:997-1032

Roodman, D. (2006). How to do xtabond2: an introduction to difference and system GMM in Stata

Russell SS, Jacobsen K, Stanley WD (1990) International Migration and Development in Sub-Saharan Africa.Discussion paper 101. World Bank, Washington, DC

Sghari MBA, Hammami S (2013) Relationship between health expenditure and GDP in developed countries. IOSR J Pharmacy, (e) -ISSN: 2250-3013, (p)-ISSN: 2319-4219. www.losrphr.org 3(4):41-45

Tan HB, Law SH (2012a) Nonlinear dynamics of the finance-inequality nexus in developing countries. J Econ Inequal 10(4): $551-563$

Tan HB, Law SH (2012b) Nonlinear dynamics of the finance-inequality nexus in developing countries. J Econ Inequal 10(4): 551-563

Taylor JE (1996) International migration and National Development. Population Index 62(2):181-212

Thirwall AP (2000) Trade, Trade Liberalization and Economic Growth: Theory and Evidence, Economic Research Paper No.63. University of Kent at Canterbury

Tita, A. F., \& Aziakpono, M. J. (2016). Financial development and income inequality in Africa: A panel heterogeneous approach.

UNDP (2009) "Overcoming Barriers: Human Mobility and Development", Human Development Report 2009. UNDP Accessed 1 Sep 2010, http://hdr.undp.org/en/media/HDR/2009_Tables_rev.xls

World Bank (2012) Global Financial Development Report 2013: Rethinking the Role of the State in Finance. World Bank, Washington, DC http://www.worldbank.org/financial development.

World Bank (2016) Poverty Reduction and Equity: Defining Welfare Measures: Monetary Dimension of Poverty" http://go. worldbank.org/W3HL5GD710 Accessed 18/08/2016 4:53 pm GMT.World Bank (2014, 2015). World Development Indicators, Washington

\section{Submit your manuscript to a SpringerOpen ${ }^{\circ}$ journal and benefit from:}

- Convenient online submission

- Rigorous peer review

- Open access: articles freely available online

- High visibility within the field

- Retaining the copyright to your article

Submit your next manuscript at $>$ springeropen.com 